Article

\title{
Electrostatic Self-Assembled Chitosan-Pectin Nano- and Microparticles for Insulin Delivery
}

\author{
Vinicius B. V. Maciel ${ }^{1,5}$, Cristiana M. P. Yoshida ${ }^{2, *}$, Susana M. S. S. Pereira ${ }^{3}$, \\ Francisco M. Goycoolea ${ }^{3,4, *}$ (iD) and Telma T. Franco ${ }^{5}$ \\ 1 Faculty of Animal Science and Food Engineering, USP-University of São Paulo, Av. Duque de Caxias \\ Norte, 225, Pirassununga CEP 13635-900, São Paulo, Brazil; viniciusbvm@usp.br \\ 2 Department of Exact and Earth Science, UNIFESP-Federal University of São Paulo, Rua São Nicolau, 210, \\ Diadema CEP 09913-030, São Paulo, Brazil \\ 3 Institut für Biologie und Biotechnologie der Pflanzen, Westfälische Wilhelms—Universität Münster, \\ Schlossgarten 3, 48149 Münster, Germany; ssoar_01@uni-muenster.de \\ 4 School of Food Science and Nutrition, University of Leeds, Leeds LS2 9JT, UK \\ 5 School of Chemical Engineering, UNICAMP—State University of Campinas, Av. Albert Einstein, 500, \\ Campinas CEP 13083-852, São Paulo, Brazil; franco@feq.unicamp.br \\ * Correspondence: cristiana.yoshida@unifesp.br (C.M.P.Y); F.M.Goycoolea@leeds.ac.uk (F.M.G)
}

Received: 14 July 2017; Accepted: 4 October 2017; Published: 12 October 2017

\begin{abstract}
A polyelectrolyte complex system of chitosan-pectin nano- and microparticles was developed to encapsulate the hormone insulin. The aim of this work was to obtain small particles for oral insulin delivery without chemical crosslinkers based on natural and biodegradable polysaccharides. The nano- and microparticles were developed using chitosans (with different degrees of acetylation: $15.0 \%$ and $28.8 \%$ ) and pectin solutions at various charge ratios $\left(\mathrm{n}^{+} / \mathrm{n}^{-}\right.$given by the chitosan/pectin mass ratio) and total charge. Nano- and microparticles were characterized regarding particle size, zeta potential, production yield, encapsulation efficiency, stability in different media, transmission electron microscopy and cytotoxicity assays using Caco-2 cells. The insulin release was evaluated in vitro in simulated gastric and intestinal media. Small-sized particles $(\sim 240-1900 \mathrm{~nm})$ with a maximum production yield of $\sim 34.0 \%$ were obtained. The highest encapsulation efficiency $(\sim 62.0 \%)$ of the system was observed at a charge ratio $\left(\mathrm{n}^{+} / \mathrm{n}^{-}\right) 5.00$. The system was stable in various media, particularly in simulated gastric fluid ( $\mathrm{pH}$ 1.2). Transmission electron microscopy (TEM) analysis showed spherical shape particles when insulin was added to the system. In simulated intestinal fluid ( $\mathrm{pH}$ 6.8), controlled insulin release occurred over $2 \mathrm{~h}$. In vitro tests indicated that the proposed system presents potential as a drug delivery for oral administration of bioactive peptides.
\end{abstract}

Keywords: chitosan; pectin; microparticles; nanoparticles; insulin; Caco-2 cells

\section{Introduction}

Chitosans are a family of polycationic aminopolysaccharides obtained from chemical or enzymatic modification of chitin. Among the key properties of chitosan, the capacity to form self-assembled electrostatic complexes with oppositely charged macromolecules, including polysaccharides, nucleic acids or proteins is one the most important. Macromolecular complexation by electrostatic self-assembly between chitosan and oppositely charged polymers can lead to highly stable colloidal systems [1,2]. Maciel et al. developed a polyelectrolyte complex matrix formed between chitosan and pectin to entrap a bioactive and hydrophilic compound (anthocyanin) that acts as a useful $\mathrm{pH}$ indicator device [3]. Some characteristics of the particles can be modified to increase the encapsulation efficiency (EE) of bioactive compound in the nanoparticles [4] such as the hydrodynamic diameter, 
morphology, zeta-potential ( $\zeta$-potential), and varying the ratio of either polymer or ionic crosslinker. Among the advocated advantages of nanostructured particles are ability to form a material resistant to acidic denaturation and enzymatic degradation, prolonging their residence time in the small intestine and hence, modulating the kinetics of release and delivery of the bioactive payload [5,6]. Rao and Geckeler [7], and Kreuter [8] have affirmed that nanoparticles could be defined as solid spherical particles usually ranging between 10-1000 $\mathrm{nm}$ and, that they are more suitable for drug delivery systems than microparticles. In this work, we have harnessed the capacity of electrostatic self-assembly of chitosan and pectin to form biocompatible macromolecular complexes that can be used in drug delivery. Pectin is a natural, low toxicity and polyanionic polysaccharide extracted from the cell walls of most plants, such as apples, oranges and pears. As chitosan does, pectin also exhibits material and bioactive properties. Chemically, it is a branched heteropolysaccharides, which consist predominantly of linear chains of partially methyl-esterified $(1,4)-\alpha$-D-galacturonic acid residues [9].

The International Diabetic Federation reported that 366 million people were affected by diabetes in 2011 and estimated that this number will increase to 552 million in 2030 [10,11]. Diabetes is one of the most lethal diseases due to its high prevalence and secondary effects. The World Health Organization [12] reported that it is responsible for thousands of deaths per year worldwide. Insulin, a protein composed by 51 amino acid residues, is the most common and effective drug used to control diabetes $[13,14]$. Peptides and proteins have been used as biopharmaceuticals due to their high activity, specificity and effectiveness compared to conventional drugs [10]. However, suitable formulations intended for oral administration based on proteins are still under development. During their transit through the gastrointestinal tract, drug molecules encounter several metabolic and physicochemical barriers. These include the harsh acidic environment of the stomach, extensive enzymatic degradation by various proteolytic enzymes, poor intestinal absorption, mucus clearance and overcoming the epithelial cell barrier [15]. The combination of these obstacles limits the systemic absorption of drugs and consequently, their therapeutic functions [16]. The use of oral formulations to deliver insulin with high bioavailability has been a subject of intense research efforts However, up to now, no successful formulations showing high insulin bioavailability have been marketed.

The use of biocompatible and biodegradable polymeric nano- and microparticles have been described as a promising strategy for oral administration of proteins such as insulin and peptides [17], providing a stable environment for the encapsulated drug [18]. An increasing number of studies have shown that polymeric nano- and microparticles are effective as drug carriers. Mukhopadhyay et al. developed self-assembled chitosan-insulin nanoparticles for oral insulin delivery and evaluated their efficiency using an in vivo diabetic model [16]. Al-Azi et al. [19] investigated insulin encapsulation, as a model drug, using high molar mass pectin-chitosan coacervates. Mukhopadhyay et al. developed chitosan-alginate nanoparticles for oral insulin administration by ionotropic pre-gelation of alginate to entrap insulin within the inner core, followed by polyelectrolyte complexation with chitosan [20]. Andreani et al. found evidence that silica nanoparticles coated with hydrophilic polymers (chitosan, sodium alginate and polyethylene glycol) can function as mucoadhesive carriers for oral insulin administration [21]. Further, Chronopoulou et al. developed an optimised drug delivery carrier (chlorhexidine) for oral mucosa use, able to deliver bioactive molecules in situ, using chitosan-based nanoparticles [22]. In turn, Zhang et al. prepared a novel polyelectrolyte complex based on cationic chitosan and anionic poly(2-acrylamide-2-methyl-propanesulfonic acid) using a polymer-monomer pair reaction system to form nanoparticles [23]. Our study complements previous works, by expanding our understanding on biopolymer-based carriers intended for oral insulin delivery. To this end, we developed insulin-loaded nano- and microparticles based on pectin and chitosan of low molar mass and two distinct degrees of acetylation (DA). We then studied the influence of the composition and DA of chitosan on the size distribution, $\zeta$-potential, production yield, stability in different biological media, insulin EE, morphology by transmission electron microscopy (TEM), cytotoxicity by Caco-2 cells and insulin in vitro release. 


\section{Results and Discussion}

\subsection{Chitosan and Pectin Characterisation}

The degrees of acetylation of chitosan (Heppe medical chitosan) $\mathrm{HMC}^{+} 85 / 5$ and $\mathrm{HMC}^{+} 70 / 5$ were $15.0 \%$ and $28.8 \%$, respectively. The intrinsic viscosity $([\eta])$ and molar mass of $\mathrm{HMC}^{+} 15 \mathrm{were}^{-1}$ $179.4 \mathrm{~mL} \cdot \mathrm{g}^{-1}$ and $2.74 \times 10^{4} \mathrm{~g} \cdot \mathrm{mol}^{-1}$, respectively, and $124.2 \mathrm{~mL} \cdot \mathrm{g}^{-1}$ and $1.75 \times 10^{4} \mathrm{~g} \cdot \mathrm{mol}^{-1}$, respectively, for $\mathrm{HMC}^{+} 70 / 5$. The degree of esterification (DE) of pectin was $68.2 \%$, being classified as a highly methoxylated pectin and the $[\eta]$ and molar mass of this polysaccharide were $429.5 \mathrm{~mL} \cdot \mathrm{g}^{-1}$ and $1.01 \times 10^{5} \mathrm{~g} \cdot \mathrm{mol}^{-1}$, respectively. The DA of chitosan, DE of pectin, as well as the polymer molar mass, are known to be important polymer characteristics to consider when forming nano- and microparticles [24-26].

\subsection{Nano- and Microparticles Characterisation}

Preliminary tests were developed to evaluate the nano- and microparticle formation over a wide range of charge ratio $\left(\mathrm{n}^{+} / \mathrm{n}^{-}\right)$(varying from 0.10 to 5.00 ). The optimal formulations were chosen, namely with excess pectin charge and excess chitosan charge. The formation of nanoand microparticles was verified visually from the solution turbidity and the absence of polymeric agglomeration, under all the tested conditions. These included various charge $\operatorname{ratios}\left(\mathrm{n}^{+} / \mathrm{n}^{-}\right)$, total charge $\left(1.0\right.$ or $\left.2.0 \times 10^{-6} \mathrm{M}\right), \mathrm{pH}(4.0,5.0,5.5$ and without $\mathrm{pH}$ adjustment) and DA of chitosan $(15.0 \%$ and $28.8 \%)$. Particles were formed using chitosan with DA of $15.0 \%$ and without adjusting the $\mathrm{pH}$ at charge ratios $\left(\mathrm{n}^{+} / \mathrm{n}^{-}\right) 2.00,4.00$ and 5.00 . Using chitosan with $28.8 \%$ DA, the best charge ratios $\left(\mathrm{n}^{+} / \mathrm{n}^{-}\right)$to form particles were $1.33,2.00,4.00$ and 5.00 .

The behaviour of each polyelectrolyte solutions and the best $\mathrm{pH}$ range to obtain further nanoand microparticles were assessed for chitosan (DA 15.0\% and 28.8\%) and pectin (Figure 1). To this end, it was measured the $\mathrm{pH}$-dependence of the $\zeta$-potential of aqueous solutions of both polyelectrolytes (chitosan and pectin) in the $\mathrm{pH}$ range evaluated (1.0-8.0).

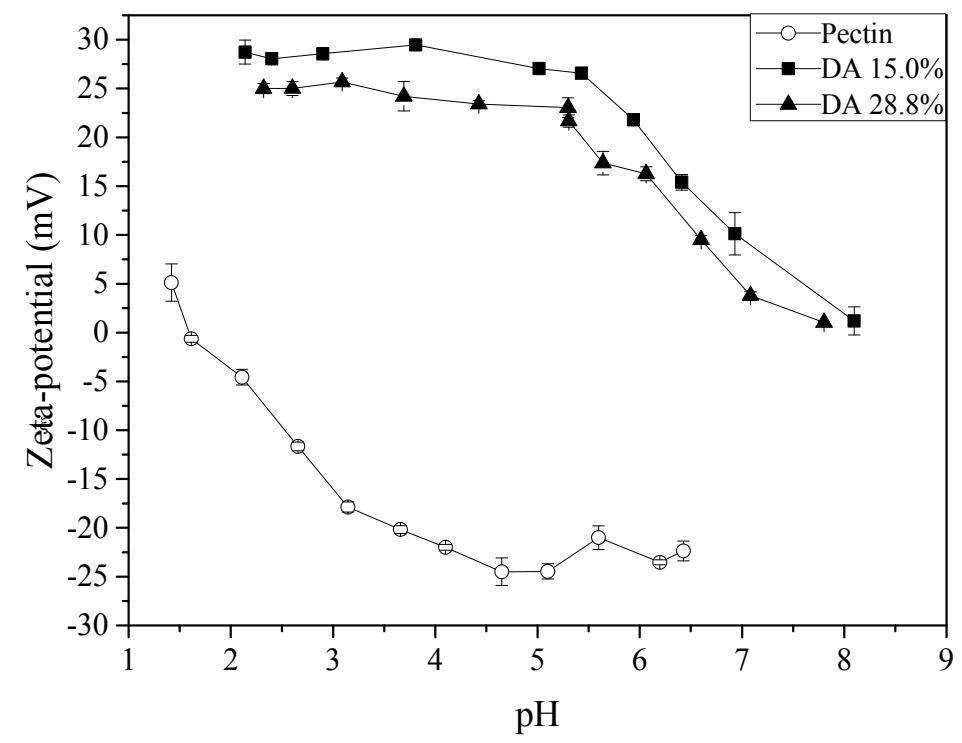

Figure 1. Variation of the $\zeta$-potential (zeta-potential) with $\mathrm{pH}$ for chitosan and pectin solutions prepared in $100 \mathrm{mM} \mathrm{NaCl}$ (as in legend) at $25^{\circ} \mathrm{C}$.

It is noted in Figure 1 that no major change in $\zeta$-potential occurred in the $\mathrm{pH}$ range of $\sim 2.0$ to $\sim 5.0$. Beyond $\mathrm{pH} 5.0$, the $\zeta$-potential decreased from $\sim+27.0$ to $\sim+7.0 \mathrm{mV}$ for both chitosan solutions. These results are consistent with the reported intrinsic $\mathrm{p} K_{\mathrm{o}}$ of chitosan $(\sim 6.1)[27,28]$. At $\mathrm{pH}<\mathrm{p} K_{\mathrm{o}}$, the amino groups of chitosan are predominantly protonated, which confers the molecule a polycationic 
character. In turn, for pectin the surface net charge remained negative $(\zeta$-potential $=\sim-25.0 \mathrm{mV}$ ) at $\mathrm{pH}>4.5$. However, at $\mathrm{pH}<4.5$, the $\zeta$-potential values decreased monotonically until nearly reaching zero at $\mathrm{pH}$ 1.5. The $\zeta$-potential is defined as the electrical potential at the hydrodynamic shear plane with respect to that of the solvent [29]. In our work, we have measured $\zeta$-potential the only as an indication of the charge state of the polyelectrolytes at the given working $\mathrm{pH}$. Measurements of $\zeta$-potential as a function of ionic strength have been used by Abodinar et al., to estimate the conformation and chain flexibility of polyelectrolytes in dilute solution and their dependence on ionic strength [30]. Although the $\zeta$-potential parameter offers a close picture of the net degree of ionization of the polyelectrolyte in solution at a given $\mathrm{pH}$, the fact that it is sensitive to the structural and conformational aspects of the polyelectrolyte, it cannot be regarded as a surrogate of potentiometric nor conductimetric measurements.

The $\zeta$-potential pH-dependence observed for pectin agrees with the reported $\mathrm{p} K_{\mathrm{a}}$ of 3.5-4.5 [31]. At $\mathrm{pH}<4.5$, the anionic character of pectin is weakened due to the dissociation of the carboxylic groups of the pectin structure [32]. In preliminary tests, we observed that when the chitosan-pectin complexes were formed at $\mathrm{pH} \sim 5.0$, agglomeration occurred. Coimbra et al. have suggested that the available charges at low $\mathrm{pH}$ could decrease the agglomeration process of the polymer solution [26].

\subsection{Zeta-Potential and Particle Size Distribution Analysis}

It was expected that pectin's carboxylate groups would interact electrostatically with oppositely charged amino functions of chitosan to form nano- and microparticles by polyelectrolyte complexation under controlled conditions to form stabilised colloidal particles. The $\zeta$-potential (proportional to the surface charge density) values of the obtained particles are shown in Figure 2. Microparticles with size less than $\sim 2500 \mathrm{~nm}$ were produced using chitosan with DA of $15.0 \%$ at $1.0 \times 10^{-6} \mathrm{M}$ total charge (Figure $2 \mathrm{a}$ ) and charge ratios $\left(\mathrm{n}^{+} / \mathrm{n}^{-}\right) 0.25$ and 5.00, with a polydispersity index of $0.25 \pm 0.06$ and $0.40 \pm 0.06$, respectively, in good keeping with previously published values [24,33]. Based on the $\zeta$-potential values (Figure $2 \mathrm{a})$, we reasoned that the charge ratios $\left(\mathrm{n}^{+} / \mathrm{n}^{-}\right)$below 1.00 presented negative values, consistent with an excess of pectin in the nano- and microparticles system. At charge ratios $\left(\mathrm{n}^{+} / \mathrm{n}^{-}\right)>1.0$, the resultant system exhibited a positive $\zeta$-potential, in expected agreement with excess chitosan. Increasing the total charge $\left(\mathrm{n}^{+}+\mathrm{n}^{-}\right)$from $1.0 \times 10^{-6}$ to $2.0 \times 10^{-6}$, produced larger particles at charge ratio $\left(\mathrm{n}^{+} / \mathrm{n}^{-}\right) 0.25$ and 5.00, with average diameters of $\sim 2500$ and $\sim 5000 \mathrm{~nm}$, respectively.

There was a very close similarity between the results observed for the systems with chitosan of DA $15.0 \%$ and those with chitosan of DA $28.8 \%$. Microparticles with size less than $1500 \mathrm{~nm}$ were obtained at charge ratio $\left(\mathrm{n}^{+} / \mathrm{n}^{-}\right) 0.25$ (Figure $2 \mathrm{c}, \mathrm{d}$ ). Negative $\zeta$-potential values (Figure $2 \mathrm{c}, \mathrm{d}$ ) were evidenced for charge ratio $\left(\mathrm{n}^{+} / \mathrm{n}^{-}\right)<0.75$, indicating an excess of pectin in the particle solution. As observed using chitosan with DA $15.0 \%$, at charge ratio $\left(\mathrm{n}^{+} / \mathrm{n}^{-}\right)>1.0$, the particles invariably attained a positive surface charge, associated with the stoichiometric surplus of chitosan. The $\zeta$-potential dependence on charge ratio $\left(\mathrm{n}^{+} / \mathrm{n}^{-}\right)$obtained for the four analysed systems revealed that regardless of chitosan DA (either $15.0 \%$ or $28.8 \%$ ) and the total concentration, the complexes were fully compensated (i.e., when the $\zeta$-potential is zero) at charge ratio $\left(\mathrm{n}^{+} / \mathrm{n}^{-}\right)$very close to the stoichiometric point $\left(\left(\mathrm{n}^{+} / \mathrm{n}^{-}\right) \sim 1.0\right)$. These results are in close agreement with those obtained in a previous study focused on chitosan (DA 20\%; molar mass $230 \mathrm{~kg} \cdot \mathrm{mol}^{-1}$ )/polyguluronate polyelectrolyte complexes [34]. In these systems, the equivalence point, as determined by conductimetric titrations, was also found at an equivalent charge ratio $\left(\mathrm{n}^{+} / \mathrm{n}^{-}\right) \sim 1.0$. From the above experiments, we selected four systems for subsequent studies of insulin loading, namely, the two chitosans (DA $15.0 \%$ and $28.8 \%$ ), two charge ratios $\left(\left(\mathrm{n}^{+} / \mathrm{n}^{-}\right) 0.25\right.$ and 5.00$)$ and $1.0 \times 10^{-6} \mathrm{M}$ total charge. 


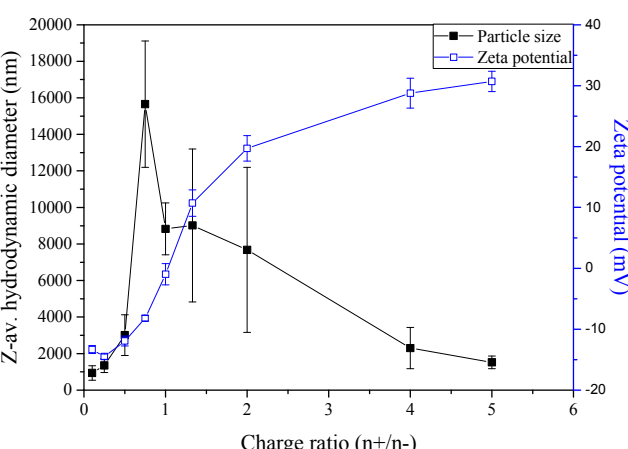

(a)

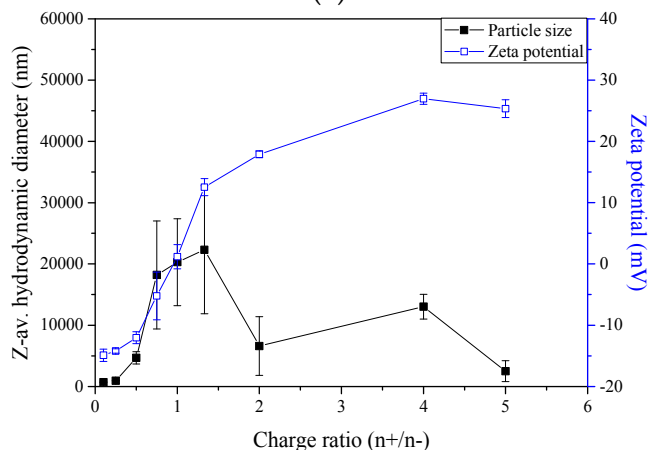

(c)

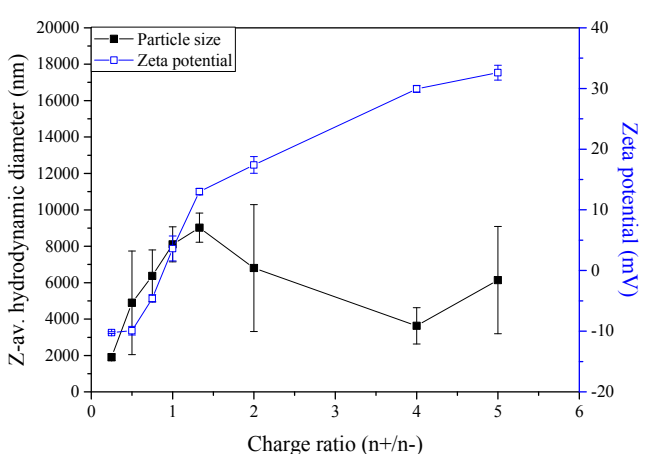

(b)

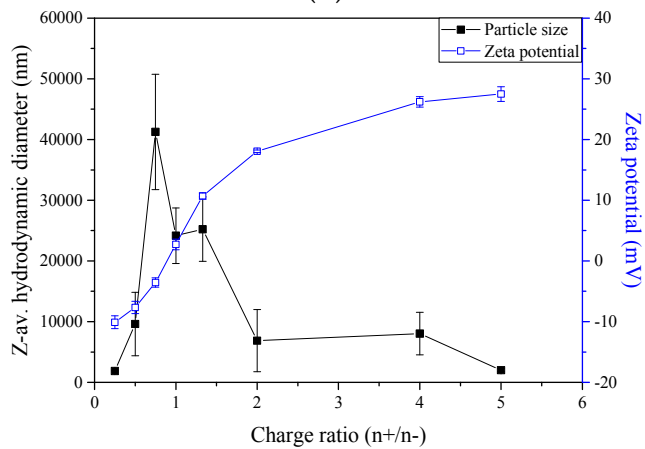

(d)

Figure 2. Variation of the Z-average hydrodynamic diameter and $\zeta$-potential with charge ratio $\left(\mathrm{n}^{+} / \mathrm{n}^{-}\right)$ of particles comprised by chitosan of different DA and pectin at $\mathrm{pH} 2.7$ and $25^{\circ} \mathrm{C}$ for systems with: (a) total charge $1.0 \times 10^{-6} \mathrm{M}$, chitosan degree of acetylation (DA) $15.0 \%$; (b) total charge $2.0 \times 10^{-6} \mathrm{M}$, chitosan DA $15.0 \%$; (c) total charge $1.0 \times 10^{-6} \mathrm{M}$, chitosan DA 28.8 ; and (d) total charge $2.0 \times 10^{-6} \mathrm{M}$, chitosan DA $28.8 \%$.

\subsection{Production Yield of Nano- and Microparticles}

The production yield of nano- and microparticles loaded with insulin or unloaded (blanks) was calculated based on the complex mass obtained after lyophilisation and the initial mass of the pectin, chitosan, $\mathrm{NaCl}$ and insulin used (Table 1).

Table 1. Particle size, $\zeta$-potential and production yield of chitosan-pectin unloaded or loaded with insulin prepared at different charge ratios $\left(\mathrm{n}^{+} / \mathrm{n}^{-}\right)$and comprising chitosans of varying degree of acetylation.

\begin{tabular}{llllll}
\hline \multirow{2}{*}{ Analysis } & \multirow{2}{*}{ Insulin } & \multicolumn{2}{l}{ Chitosan DA 15.0\% } & \multicolumn{2}{l}{ Chitosan DA 28.8\% } \\
\cline { 3 - 6 } & & \multicolumn{2}{l}{ Charge Ratio $\left(\mathbf{n}^{+} / \mathbf{n}^{-}\right)$} & \multicolumn{2}{l}{ Charge Ratio $\left(\mathbf{n}^{+} / \mathbf{n}^{-}\right)$} \\
\cline { 3 - 6 } & & $\mathbf{0 . 2 5}$ & $\mathbf{5 . 0 0}$ & $\mathbf{0 . 2 5}$ & $\mathbf{5 . 0 0}$ \\
\hline \multirow{2}{*}{ Particles size $(\mathrm{d}, \mathrm{nm})$} & Blank & $2530 \pm 384^{\mathrm{aA}}$ & $2618 \pm 175^{\mathrm{aA}}$ & $1875 \pm 135^{\mathrm{aA}}$ & $2011 \pm 266^{\mathrm{aA}}$ \\
& Loaded & $1351 \pm 384^{\mathrm{aB}}$ & $1522 \pm 346^{\mathrm{aB}}$ & $964 \pm 32^{\mathrm{aB}}$ & $2510 \pm 107^{\mathrm{bB}}$ \\
\hline \multirow{2}{*}{$\zeta$-potential $(\mathrm{mV})$} & Blank & $-22.5 \pm 0.8^{\mathrm{aA}}$ & $+35.0 \pm 1.4^{\mathrm{bA}}$ & $-23.4 \pm 0.9^{\mathrm{aA}}$ & $+27.2 \pm 1.4^{\mathrm{bA}}$ \\
& Loaded & $-22.5 \pm 2.5^{\mathrm{aA}}$ & $+33.2 \pm 2.3^{\mathrm{bA}}$ & $-22.4 \pm 2.4^{\mathrm{aA}}$ & $+28.6^{\mathrm{a}} \pm 2.0^{\mathrm{bA}}$ \\
\hline \multirow{2}{*}{ Production yield (\%) } & Blank & $23.8 \pm 1.1^{\mathrm{aA}}$ & $18.9 \pm 3.0^{\mathrm{bA}}$ & $22.6 \pm 0.6^{\mathrm{aA}}$ & $23.7 \pm 3.3^{\mathrm{aA}}$ \\
& Loaded & $27.2 \pm 3.9^{\mathrm{aA}}$ & $33.8 \pm 4.3^{\mathrm{aB}}$ & $24.3 \pm 2.0^{\mathrm{aA}}$ & $22.4 \pm 2.0^{\mathrm{aA}}$ \\
\hline
\end{tabular}

$\mathrm{a}, \mathrm{b}$ : Average of different letters in the same line for the same analysis and type of chitosan differ statistically $(p<0.05)$ by Tukey test. ${ }^{A}, \mathrm{~B}$ : Average of different letters in the same column for the same analysis and type of chitosan differ statistically $(p<0.05)$ by Tukey test.

Inspection of Table 1 shows that the nano- and microparticles average hydrodynamic diameter was smaller after insulin loading, except for chitosan with a DA $28.8 \%$ at charge ratio $\left(\mathrm{n}^{+} / \mathrm{n}^{-}\right) 5.00$. 
This could indicate that the substitution of pectin by insulin at equivalent charge concentration considerably changed the particle size. An electrostatic interaction between the bioactive polypeptide and polymers (chitosan and pectin) could promote the small particles formation in solution, avoiding agglomerates of particles with greater size. The process of insulin addition to the nano- and microparticles was efficient, as there were no significant differences $(p<0.05)$ between the $\zeta$-potential of the blank and insulin-loaded formulations.

Overall, higher production yields were obtained for the nano- and microparticles containing insulin than the blank ones. Particularly, in the formulations based on chitosan with DA $15.0 \%$ and charge ratio $\left(\mathrm{n}^{+} / \mathrm{n}^{-}\right) 5.00$, for which the increment in yield was $~ 100 \%(18.9 \%$ to $33.8 \%$ for blank and insulin-loaded systems, respectively). In the other systems studied, the insulin loading only moderately increased the yield (less than 10\%). In general, our yield values agree with those of previous studies on chitosan-tripolyphosphate nano- and microparticles for drug delivery that found production yields ranging from $38-51 \%$ [35], $12-48 \%$ [36], and $24-84 \%$ [37].

\subsection{Stability of Insulin-Loaded Nano- and Microparticles}

The stability of insulin-loaded nano- and microparticles was evaluated by analysing the evolution of the particle size upon incubation in $150 \mathrm{mM} \mathrm{NaCl}$ (pH 7.4), minimal essential medium (MEM, pH 7.4), simulated gastric fluid (SGF, pH 1.2) and simulated intestinal fluid (SIF, $\mathrm{pH}$ 6.8), at $37 \pm 1{ }^{\circ} \mathrm{C}$ for $24 \mathrm{~h}$ (Figure 3). As shown in Figure 3a, the particle size obtained from chitosan with DA $28.8 \%$ and charge ratio $\left(\mathrm{n}^{+} / \mathrm{n}^{-}\right) 5.00$ increased 4-fold after incubation in $150 \mathrm{mM} \mathrm{NaCl}$ for $24 \mathrm{~h}$ (from 5.0 to $20.0 \mu \mathrm{m}$ ). In contrast, the particle size obtained from chitosan with DA $28.8 \%$ and charge ratio $\left(\mathrm{n}^{+} / \mathrm{n}^{-}\right) 0.25$ (i.e., a surplus of negatively charged pectin) was notably smaller and remained stable at $24 \mathrm{~h}$. Particles of smaller size tend to be more stable than larger particles against aggregation under physiological conditions, and are known to be also more effective to promote the absorption process of proteins through the intestinal epithelium [20,23]. Further, the particle size is an important characteristic to determine the absorption process, distribution, and in vivo performance of nanoparticles; it also influences the drug loading capacity and in vitro release characteristics of nanoparticles. In general, nanoparticles exhibit higher cellular uptake efficiency than do the larger size microparticles $[14,21]$. Nanoparticles with a particle size $<100 \mathrm{~nm}$ administered orally are known to be efficiently taken up in Peyer's patches, and then absorbed into systemic circulation [38]. The evolution of the particle size in physiological conditions ( $150 \mathrm{mM} \mathrm{NaCl}$ and $\mathrm{pH} 7.4)$ is an indicator of the stability of colloidal particles during exposure to physiological isotonic conditions [39]. Interestingly, Lu et al. also observed that insulin-loaded polyelectrolyte complex nanoparticles of poly(glycerol methacrylate)s (cationic polymer) increased in size from 250 to $3000 \mathrm{~nm}$ upon increasing the $\mathrm{NaCl}$ concentration from 0.020 to $0.100 \mathrm{M}$ [40]. They attributed this behaviour to the salt action, which could facilitate the polysaccharide complexation, thus resulting in larger particles size.

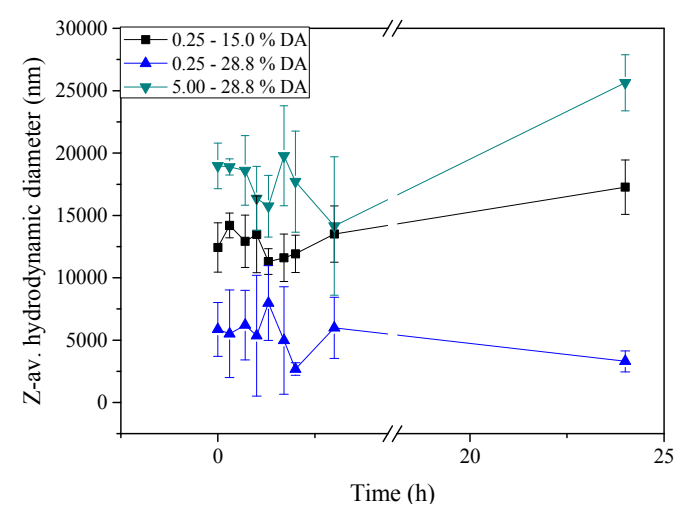

(a)

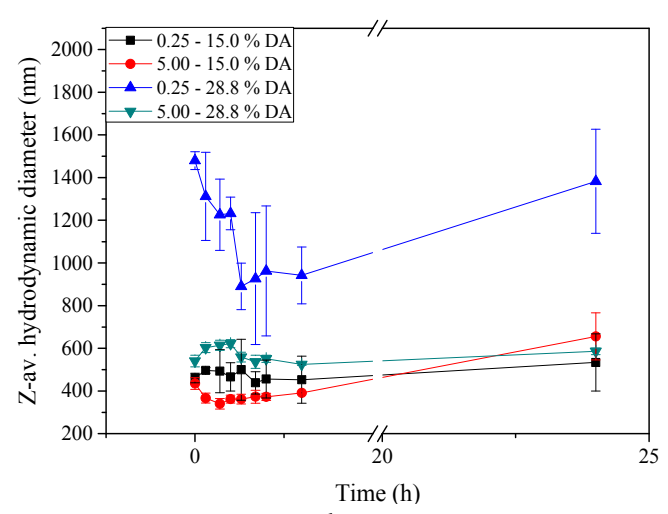

(b)

Figure 3. Cont. 


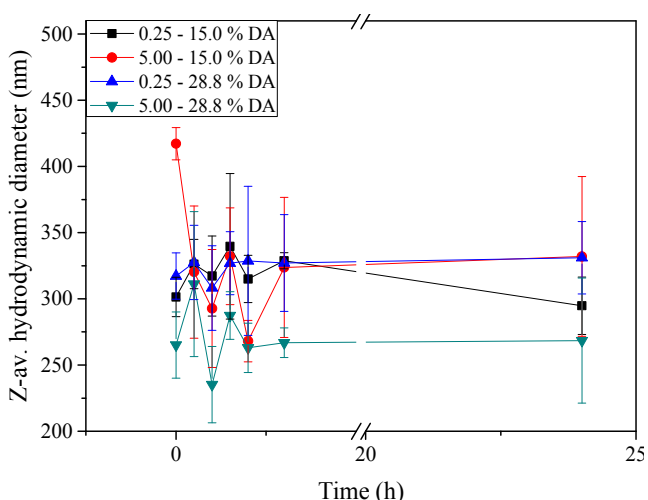

(c)

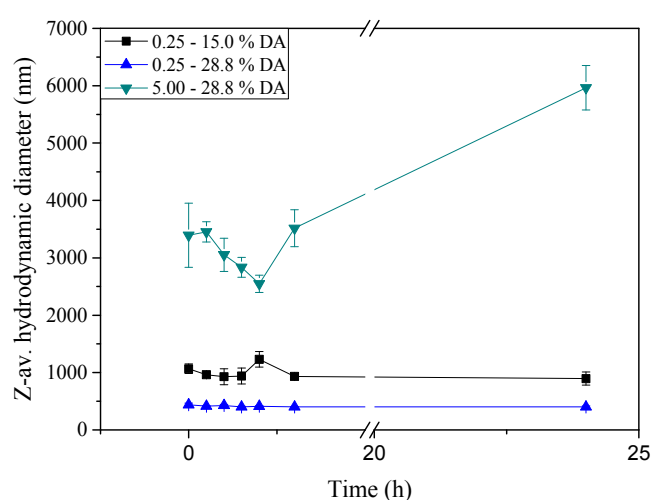

(d)

Figure 3. Evolution of the $\zeta$-average hydrodynamic diameter of insulin-loaded particles comprised by chitosans of varying DA and pectin mixed at different charge ratio $\left(\mathrm{n}^{+} / \mathrm{n}^{-}\right.$as shown in labels) during incubation at $37 \pm 1{ }^{\circ} \mathrm{C}$ for $24 \mathrm{~h}$ in: (a) $150 \mathrm{mM} \mathrm{NaCl}$ (pH 7.4); (b) MEM (minimal essential medium, pH 7.4); (c) SGF (simulated gastric fluid, $\mathrm{pH} 1.2$ ) and (d) SIF (simulated intestinal fluid, $\mathrm{pH}$ 6.8).

In general, the systems showed greater stability when incubated in MEM than in $\mathrm{NaCl}$ (Figure 3b). The average particle size in this instance was also significantly smaller ( 300- 1600 nm). At $24 \mathrm{~h}$ incubation, the particle size remained below $700 \mathrm{~nm}$, except for the formulation using chitosan with DA $28.8 \%$ and charge ratio $\left(\mathrm{n}^{+} / \mathrm{n}^{-}\right) 0.25$ that exhibited overall larger particle sizes after incubation. In previous studies, it was observed that chitosan-based nanocapsules obtained from chitosans of varying DA, were stable in cell culture medium, particularly those comprised by chitosan of high DA and low molecular weight [41]. We have argued that the hydrophilic nature of chitosan at the surface of these systems results in a stabilization mechanism based on short-range repulsive hydration forces. Russo et al. evaluated the stability of chitosan nanoparticles loaded with foscarnet, an antiviral agent, in phosphate buffered saline (PBS) at $37^{\circ} \mathrm{C}$ and observed a gradual increase in particle size during the first $5 \mathrm{~h}$ [42]. To minimise this behaviour, the authors suggested adding a crosslinker (glutaraldehyde) to a particle preparation. This study also highlights the role of the polymers mobility on the overall colloidal stability at the surface of the particles. These effects seen previously by Russo et al. on the polymers mobility could also be observed in the chitosan/pectin complexes [42]. The behaviour of insulin-loaded nano- and microparticles was further evaluated in SGF (Figure 3c) and SIF (Figure 3d). The particle size upon incubation in SGF remained within $240-420 \mathrm{~nm}$, and this persisted for $24 \mathrm{~h}$.

Nano- and microparticles obtained at charge ratio $\left(\mathrm{n}^{+} / \mathrm{n}^{-}\right) 0.25$, independent of chitosan's DA, showed particle diameters $\sim 1000 \mathrm{~nm}$ after incubation in SIF. Increasing the charge ratio $\left(\mathrm{n}^{+} / \mathrm{n}^{-}\right)$from 0.25 to 5.00 (i.e., excess of positive charges from chitosan), the particles only remained stable for $3 \mathrm{~h}$. Beyond this time, the particle size gradually increased upon incubation for up to $24 \mathrm{~h}$. At $\mathrm{pH}$ close to neutrality, such as under SIF conditions, chitosan is practically non-ionised [27], which may explain the instability of the systems with excess chitosan. The increase in particle size can be attributed to aggregation of the particles rather than to swelling, as evidenced dynamic light scattering (DLS, results not shown).

Our results agree well with those of Bagre et al. who studied controlled delivery of enoxaparin from chitosan nanoparticles coated with alginate and found that the particles were not stable upon incubation in SIF ( $\mathrm{pH}$ 7.4) [43]. They attributed this to the sensitivity of chitosan at the physiological $\mathrm{pH}$ of intestinal fluid after the dissolution of the alginate coat. Luo et al. evaluated the stability of lipid nanoparticles coated with chitosan intended for oral application, observing adequate results under acidic conditions [44]. The stability of insulin-loaded chitosan microspheres was evaluated under gastric $\mathrm{pH}$, verifying that the insulin was protected from enzymatic degradation in this medium [45]. 


\subsection{Insulin Encapsulation Efficiency (EE)}

The EE of the insulin-loaded chitosan-pectin nano- and microparticles with different charge ratios $\left(\mathrm{n}^{+} / \mathrm{n}^{-}, 0.25\right.$ and 5.00$)$ and DA of chitosan $(15.0 \%$ and $28.8 \%)$ are shown in Table 2. An EE of $34-37 \%$ of insulin was achieved for systems with charge ratio $\left(\mathrm{n}^{+} / \mathrm{n}^{-}\right) 0.25$. The EE was further improved $(62 \%)$ for systems with charge ratio $\left(\mathrm{n}^{+} / \mathrm{n}^{-}\right) 5.00$, independent of DA of chitosan. We reason that the excess of positive chitosan charges considerably influenced the insulin loading of the nano- and microparticles.

Table 2. Encapsulation efficiency (EE) of insulin at the nano- and microparticles prepared in different charge ratios $\left(\mathrm{n}^{+} / \mathrm{n}^{-}\right)$and degree of acetylation (DA) of chitosan.

\begin{tabular}{cccc}
\hline Formulation & Charge Ratio $\left(\mathbf{n}^{+} / \mathbf{n}^{-}\right)$ & DA (\%) & EE (\%) \\
\hline 1 & 0.25 & 15.0 & $36.6 \pm 6.6^{\mathrm{a}}$ \\
2 & 5.00 & 15.0 & $62.2 \pm 3.1^{\mathrm{b}}$ \\
3 & 0.25 & 28.8 & $34.2 \pm 8.1^{\mathrm{a}}$ \\
4 & 5.00 & 28.8 & $61.9 \pm 0.5^{\mathrm{b}}$ \\
\hline
\end{tabular}

$\mathrm{a}, \mathrm{b}$ : Average of different letters in the same column differ statistically $(p<0.05)$ by Tukey's test.

Ideal nanoparticulate systems must have a high drug EE [46]. Different bioactive molecules, particularly biologics (e.g., enzymes, peptides, monoclonal antibodies), should maintain their bioactive conformation as to display the desired bioactive effects in vivo. Electrostatic interactions between the acidic groups of insulin and/or anionic polymers and amino groups of chitosan have important effects in the EE of insulin in chitosan-tripolyphosphate nanoparticles [47].

In previous studies focused on insulin-loaded nanoparticles comprised by polyelectrolyte complexation of chitosan and alginate and concomitantly by ionic gelation with tripolyphosphate, it was determined insulin encapsulation efficiency of $41-52 \%$ [48]. The chitosan/insulin mass ratio in these studies was fixed at 2.0 and in the present work varied between 0.4 and 0.5 (depending on DA of chitosan). However, in the mentioned studies they did not address the influence of the charge stoichiometry of chitosan to alginate, as we have done in the present work. It is clear from our results, that the composition of the system, determined by the proportional amount of chitosan is what governs the net amount of associated insulin. We propose that the association of insulin is mediated predominantly by electrostatic interactions between oppositely charged chitosan and insulin. The fact that the overall production yield was lower for the systems comprised by the chitosan of lower charge density (i.e., DA 28.8\%) seems consistent with the idea that insulin is associated at the expense of the complexation of chitosan with pectin, as we have observed before in the chitosan-alginate-TPP (tripolyphosphate) nanoparticles [49].

Many studies have addressed the development of nanoparticles for oral delivery of insulin. Pan et al. found that chitosan nanoparticles can improve the intestinal absorption of insulin in alloxan-induced diabetic rats in up to $80 \%$ EE [49]. Bayat et al. reported that the insulin-loaded nanoparticles formed from chitosan and its derivatives (triethyl- and dimethylethylchitosan) had an EE between 84-90\% [46]. Mukhopadhyay et al. produced self-assembled chitosan-insulin nanoparticles and obtained an insulin EE around 85\% [16]. Al-Azi et al. found relatively lower values of EE, namely $5 \%$, in insulin-loaded nanoparticles produced by complex coacervation between chitosan and pectin [19]. They attributed such low insulin association capacity to the low coacervation rate between the high molar mass polymers. Other studies have focused on the use of chitosan-based polyelectrolyte complex systems for drug delivery. Jardim et al. synthesised chitosan-chondroitin sulphate nanoparticles curcumin-loaded and found EE of curcumin ranged from $62.4 \pm 0.61 \%$ to $68.3 \pm 0.88 \%$ [5]. Zhang et al. prepared a polyelectrolyte complex based on chitosan and poly(2-acrylamide-2-methylpropanesulfonic acid) using a polymer-monomer pair reaction system and found the EE of doxorubicin 61-64\% [23]. 


\subsection{Transmission Electron Microscopy}

Images of nano- and microparticles non-loaded or insulin-loaded were recorded by transmission electron microscopy (TEM) and analysed in terms of morphology and surface topology. Representative images of the systems formulated using chitosan DA $28.8 \%$ at two different charge ratios $\left(\mathrm{n}^{+} / \mathrm{n}^{-}\right.$, 0.25 and 5.00) are shown in Figure 4. Very similar micrographs were recorded for systems comprised by chitosan DA $15.0 \%$ (results not shown). It was interesting to notice that the systems loaded with insulin revealed a more spherical morphology (Figure 4c,d) than the corresponding blank ones, independently of the charge ratio $\left(\mathrm{n}^{+} / \mathrm{n}^{-}\right)$. Insulin-loaded chitosan particles presenting spherical shape and smooth surface have also been found in previous studies [16,48]. The range of particle size observed in the TEM images in all cases seems smaller compared to those obtained from DLS analysis. This could be the expected consequence of the larger abundance by number of smaller particles over the larger ones, hence these are more likely to be better imaged in suitable windows of the grid during TEM. Also, the hydrodynamic diameter of freshly prepared nano- and microparticles measured by DLS may be expanded due to swelling, whereas such effect is likely to be abrogated during the preparation of the specimens for TEM [20].
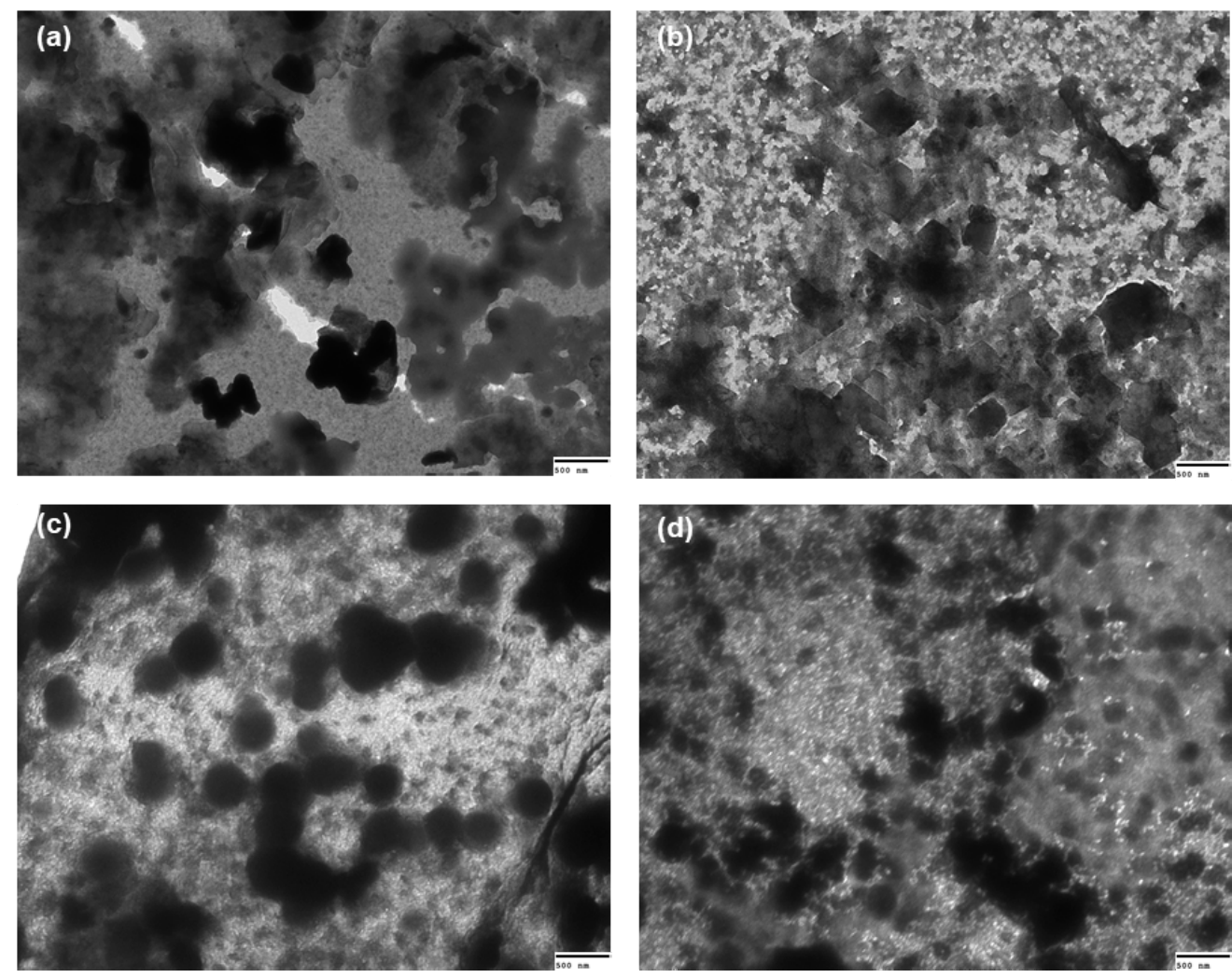

Figure 4. Representative transmission electron microscopy (TEM) images of (a) blank (unloaded) particles (chitosan DA $28.8 \%$ and charge ratio $\left(\mathrm{n}^{+} / \mathrm{n}^{-}\right)$0.25); (b) Blank (unloaded) particles (chitosan DA $28.8 \%$ and charge ratio $\left(\mathrm{n}^{+} / \mathrm{n}^{-}\right) 5.00$ ); (c) insulin-loaded (chitosan DA $28.8 \%$ and charge ratio $\left(\mathrm{n}^{+} / \mathrm{n}^{-}\right)$0.25); and (d) insulin-loaded (chitosan DA $28.8 \%$ and charge ratio $\left.\left(\mathrm{n}^{+} / \mathrm{n}^{-}\right) 5.00\right)$.

\subsection{Cytotoxicity (MTT (3-(4,5-Dimethylthiazolyl-2)-2,5-diphenyltetrazolium bromide) Assay)}

Evaluation of the cytocompatibility of any new drug delivery biomaterial is a crucial step in its development, as it offers a first in vitro proof-of-concept of its biocompatibility of [50]. The MTT assay is the most common method to assess the effect of either biomaterials or bioactive compounds using mammalian cell lines in culture [51,52]. This also enables comparisons with previous studies. 
The reduction of MTT, a yellow tetrazolium salt, occurs by metabolically competent mitochondria. After reduction, a violet formazan dye is formed, and the metabolic competence (assumed to be directly proportional to the cell viability) can be quantified spectrophotometrically by comparing the results to the corresponding positive and negative controls [53]. Caco-2 cells are frequently used as representative cells of the human intestine due to their capacity to spontaneously differentiate after 3-4 weeks into highly polymerised phenotypes [54] with functional tight junctions in porous membranes [55].

In this study, the in vitro cytotoxicity of the chitosan-pectin nano- and microparticles at different concentrations was evaluated by MTT tests (Figure 5). Blank nano- and microparticles showed cell viability values above $90 \%$ (Figure $5 \mathrm{a}$ ) and $80 \%$ (Figure $5 \mathrm{c}$ ), irrespective of the chitosan's DA and the chitosan-pectin charge ratio $\left(\mathrm{n}^{+} / \mathrm{n}^{-}\right)$. No dose-response effect was observed upon treating the cells with particle concentrations from $5-100 \mu \mathrm{g} \cdot \mathrm{cm}^{-2}$. Cell viability did not decrease even after incubation at $37^{\circ} \mathrm{C}$ for $4 \mathrm{~h}$. In all the blank formulations, the particles neither showed any particular cytotoxicity nor influenced the normal growth of Caco-2 cells within the dose range studied $\left(\leq 100 \mu \mathrm{g} \cdot \mathrm{cm}^{-2}\right)$. However, the insulin-loaded particles decreased the cell viability, which was influenced by the chitosan's DA (Figure 5b,d). While moderate decreases (75-95\%) in cell viability were observed for the systems using chitosan with DA $15 \%$ (Figure 5 c), the decrease was notably more evident $(55-70 \%)$ in the treatments comprising chitosan DA $28.8 \%$ (Figure $5 \mathrm{~d}$ ) at both the chitosan/pectin equivalent charge ratios $\left(\mathrm{n}^{+} / \mathrm{n}^{-}\right)$studied.

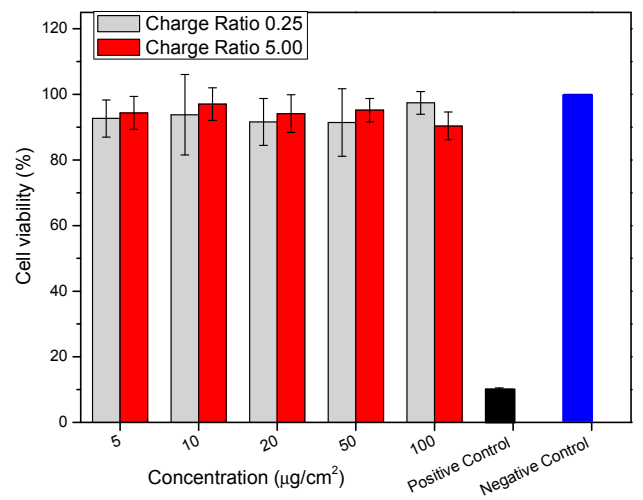

(a)

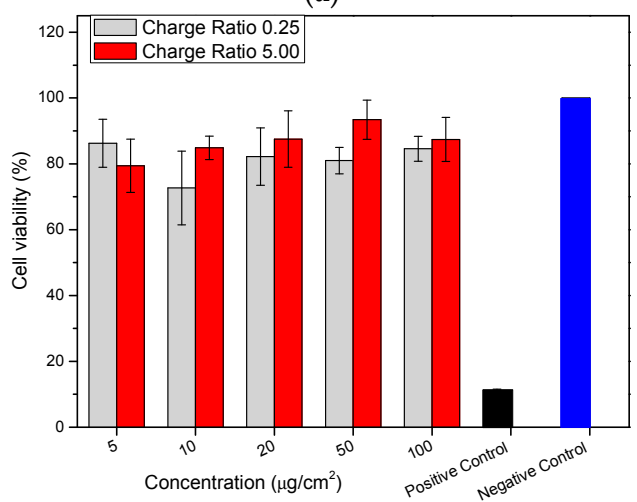

(c)

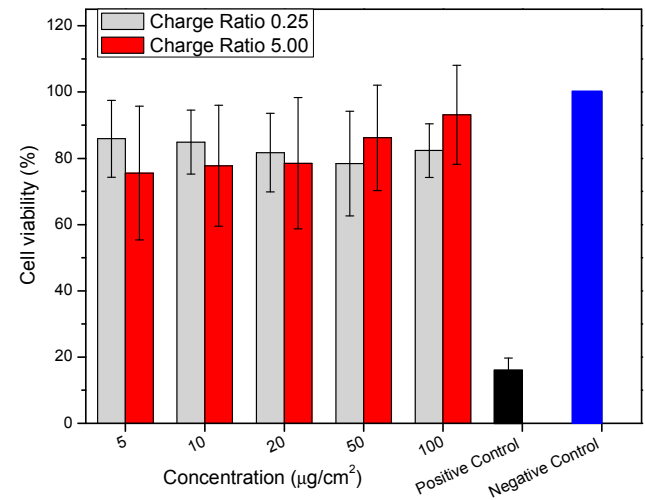

(b)

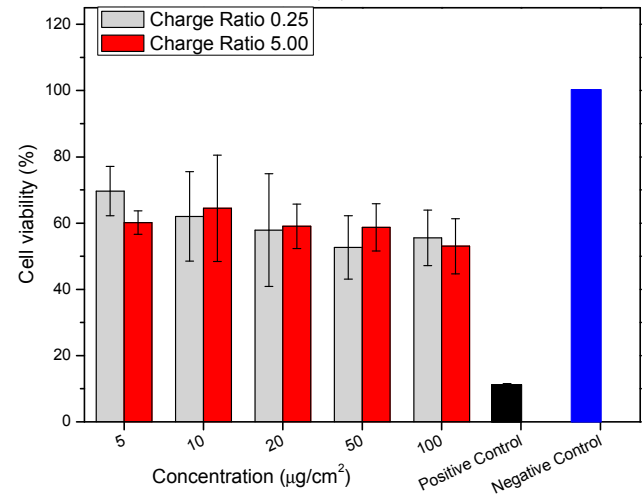

(d)

Figure 5. Cell viability (MTT (3-(4,5-dimethylthiazolyl-2)-2,5-diphenyltetrazolium bromide) assay) of Caco-2 cells after treatment $\left(4 \mathrm{~h}\right.$ at $37 \pm 0.1^{\circ} \mathrm{C}$ ) varying concentrations of nano- and microparticles at different charge ratio $\left(\mathrm{n}^{+} / \mathrm{n}^{-}\right)$(as in figure legends). (a) Blank (unloaded) particles, chitosan DA 15.0\%; (b) Insulin-loaded, chitosan DA 15.0\%; (c) Blank (unloaded) particles, chitosan DA 28.8\% and (d) Insulin-loaded, chitosan DA $28.8 \%$ (values represent average and standard deviations of three biological replicates). 
The significantly accentuated decrease in cell viability observed for the insulin-loaded systems using chitosan with DA $28.8 \%$ compared to chitosan with DA $15.0 \%$, reveals that the DA of chitosan was an important characteristic that influenced the cytocompatibility of these systems. An overall lower cell viability and a dose-response at increasing concentrations (from 5.0 to $100 \mu \mathrm{g} \cdot \mathrm{cm}^{-2}$ ) were observed for the particles using chitosan with DA $28.8 \%$ than for those comprising chitosan of DA $15.0 \%$. This could be attributed to the role of insulin as an endogenous hormone that can interfere with normal cell metabolism [50]. The differences in cell viability associated with the DA of chitosan could stem from the greater intracellular delivery achieved by the particles using chitosan with DA $28.8 \%$ than the more highly-charged chitosan.

Previous studies have addressed the cytocompatibility of chitosan-based nanoparticle formulations. Loretz and Bernköp-Schnurch proposed that in general, the decrease in Caco-2 cell viability upon treatment with chitosan (low viscosity and DA 19.0\%) could result from electrostatic interactions between chitosan nanoparticles and the cell membrane [56]. This was confirmed by Soliman et al. who reported a simple and bioinspired nanoparticulate system by preparing hydrocaffeic acid-chitosan conjugates loaded with bovine serum albumin [39]. They found accentuated cell viability decreases in the presence of the drug. Biswas et al. developed and characterized sodium alginate coated chitosan $(42,74$ and $106 \mathrm{kDa}$ ) nanoparticles, in which the measles antigen was entrapped and found no significant difference in cell viability [57]. In another study, Jia et al. studied the transport of chitosan (14\% DA) nanoparticles across Caco-2 cell monolayers [58]. They found that the cytotoxicity was mainly influenced by the molar mass of chitosan $(200 \mathrm{kDa})$ and its cationic charge density, promoting a high degree of interaction between chitosan and the cell membrane. Sadeghi et al. evaluated the permeation of insulin-chitosan nanoparticles through a Caco-2 cell monolayer using chitosan and its derivatives (trimethyl-, dimethylethyl-, diethylmethyl- and triethylchitosan) and concluded that the polymers did not exert any cytotoxicity (less than 1.0\% dead cells) [59]. Similar results were reported by Zhang and Zhao who investigated chitosan nanoparticles and found cell viability values above $84.0 \%$ [36].

\subsection{Insulin Release: In Vitro Tests}

Insulin release from nano- and microparticles prepared using different chitosans (DA 15.0\% and $28.8 \%$ ) at charge ratio $\left(\mathrm{n}^{+} / \mathrm{n}^{-}\right) 5.00$ (selected from the higher EE values) was studied in SGF (pH 1.2) (Figure 6a) and SIF (pH 6.8) (Figure 6b) for 120 min, respectively. The chitosan DA did not influence the process of insulin release, presenting similar behaviour under both conditions. In SGF, initially, a small amount of insulin was released ( $2 \%$ ) (Figure 6a), followed by a controlled release that after $120 \mathrm{~min}$ did not exceed $\sim 13 \%$. Note that the overall release of insulin in SGF (pH 1.2) was much lower than that in simulated intestinal fluid ( $\mathrm{pH}$ 6.8). This is believed to be caused by the weak electrostatic interaction between the insulin, bearing a highly positive net charge, and the polyelectrolytes on the surface. Further, insulin released from nano- and microparticles comprising the two chitosans (DA 15.0\% and $28.8 \%$ ) in conditions that simulated the human intestine ( $\mathrm{pH} 6.8$ ) was controlled (Figure $6 \mathrm{~b}$ ) and attained a maximum of $89.0 \%$ after $120 \mathrm{~min}$.

The insulin delivery from nano- and microparticles carried out in SIF (Figure 6b) showed a controlled and slightly prolonged insulin release, amounting to $87.0-89.0 \%$ of its initial amount. This could be due to the strong interaction between the alkaline solvent and positively charged chitosan shell, facilitating the penetration of the solvent towards the pectin core. In contrast, the positive charges from chitosan and the tight pectin network could help to retain the insulin at $\mathrm{pH} 1.2$ and protect the encapsulated insulin against proteolytic degradation in the stomach [16]. The behaviour of insulin release under acidic conditions is in accordance with previous studies $[21,43,60]$. However, the rapid insulin delivery at $\mathrm{pH} 6.8$ was an unexpected result.

For the measles antigen entrapped in coated and uncoated chitosan nanoparticles, Bagre et al. found that the antigen was rapidly delivered ( $40.0 \%$ in $2 \mathrm{~h}$ ) in SGF using the uncoated nanoparticles, which was associated to the high solubility of chitosan at low $\mathrm{pH}$ [43]. Biswas et al. observed rapid 
antigen delivery ( 20.0\%) from chitosan nanoparticles in PBS (pH 7.4) at $3 \mathrm{~h}$ [57]. The authors attributed this to a weak ionic interaction between the bioactive and chitosan, which could be easily desorbed in an ionic environment. Mukhopadhyay et al. prepared chitosan-alginate nanoparticles to incorporate insulin and evaluated the delivery process in gastric ( $\mathrm{pH}$ 1.2) and intestinal ( $\mathrm{pH} 6.8$ and 7.4) media [21]. Rapid delivery of insulin (26.7\%) was observed in the gastric medium after $2 \mathrm{~h}$, which was attributed to weak interactions between insulin and the poly-electrolytes. In SIF, however, a slow and modulated delivery of insulin (79.0-84.0\%) was found at $24 \mathrm{~h}$.

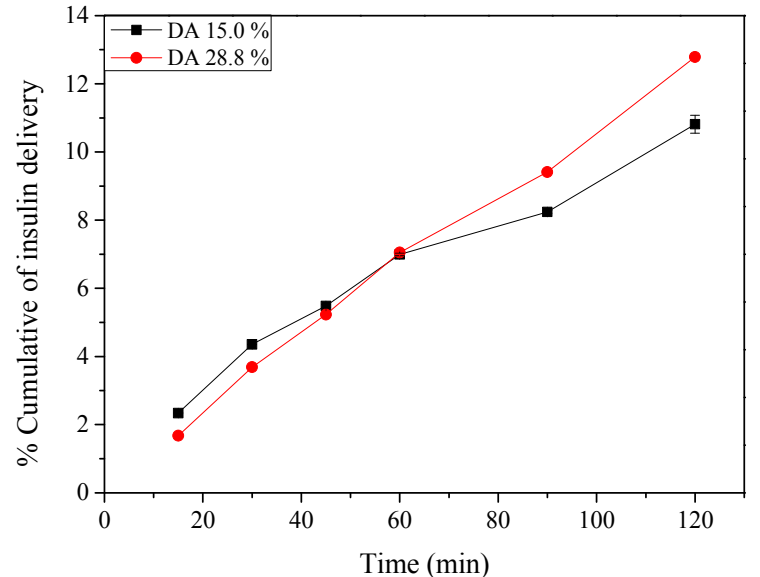

(a)

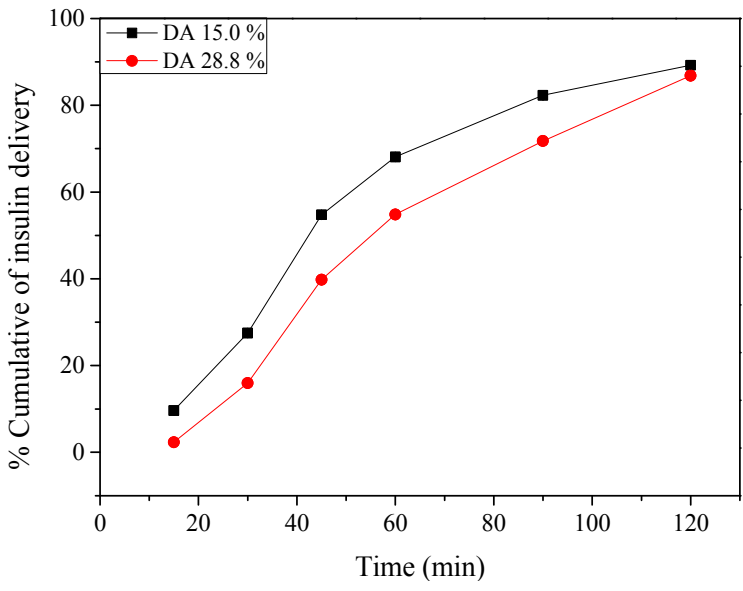

(b)

Figure 6. Percentage cumulative of insulin release from nano- and microparticles prepared using chitosan of different DA and pectin at charge ratio $\left(\mathrm{n}^{+} / \mathrm{n}^{-}\right) 5.00$ during incubation for $120 \mathrm{~min}$ at $37 \pm 0.1^{\circ} \mathrm{C}$ in: (a) Simulated gastric fluid ( $\left.\mathrm{pH} 1.2\right)$ and (b) Simulated intestinal fluid ( $\mathrm{pH}$ 6.8).

\section{Materials and Methods}

\subsection{Materials}

Two high-purity, research grade chitosan samples (chitosan 85/5 Nr. 23500, lot 212-300811-03, herein referred to as sample "HMC ${ }^{+} 15^{\prime}$, and chitosan 70/5 Nr. 23200, lot 212-111111-03, herein referred to as sample "HMC" 28.8"), were purchased from Heppe Medical Chitosan GmbH (Halle, Germany) and used as received; pectin (from citrus peel) with a high DE (GENU ${ }^{\circledR} 105$ rapid set, lot LI03024) was from CPKelco (Limeira, Brazil); and recombinant human insulin (molar mass of $5.7 \mathrm{kDa}$, lot 11D762J) was from SAFC (Lenexa, KS, USA). All reagents were of analytical grade. Ultrapure MilliQ water was used throughout.

\subsection{Methods}

\subsubsection{Determination of the Degree of Acetylation of Chitosan}

The DA of the chitosan samples was determined by ${ }^{1} \mathrm{H}-\mathrm{NMR}$ spectroscopy, per the procedure of Lavertu et al. [61], using a DRX 500 spectrometer (Bruker, Fallanden, Switzerland). Briefly, chitosan powder $(5.0 \mathrm{mg})$ was dissolved in $1.0 \mathrm{~mL} \mathrm{HCl}(37 \%)$, frozen at $-20{ }^{\circ} \mathrm{C}$ for $24 \mathrm{~h}$, then lyophilised for $12 \mathrm{~h}$. After, the sample was dissolved in $1.0 \mathrm{~mL}$ of deuterated water $\left(\mathrm{D}_{2} \mathrm{O}\right)$. The spectra were acquired at $25{ }^{\circ} \mathrm{C}$. The DA (\%) was calculated using integrals of the peak of the proton of deacetylated monomer $\left(\mathrm{H}_{1} \mathrm{D}\right)$ and of the peak of the three protons of the acetyl group $(\mathrm{H}-\mathrm{Ac})$, i.e., $\mathrm{DA}(\%)=100-\left[\left[\mathrm{H}_{1} \mathrm{D} /\left(\mathrm{H}_{1} \mathrm{D}\right.\right.\right.$ $+\mathrm{H}-\mathrm{Ac} / 3)] \times 100]$. 


\subsubsection{Determination of Intrinsic Viscosity ([ $\eta])$ and Molar Mass Estimation of Chitosans}

The $[\eta]$ of the chitosan samples was determined according to Rinaudo et al. [62]. Briefly, $\mathrm{HMC}^{+}$ 15 chitosan solutions $\left(1.25,1.50,1.75,2.00\right.$ and $\left.2.50 \mathrm{mg} \cdot \mathrm{mL}^{-1}\right)$ and $\mathrm{HMC}^{+} 28.8$ solutions $(2.00,2.50$, 3.00, 4.00 and $5.00 \mathrm{mg} \cdot \mathrm{mL}^{-1}$ ) were prepared in $0.3 \mathrm{M} \mathrm{AcOH} / 0.2 \mathrm{M} \mathrm{AcONa}$. The relative viscosity was measured using a model AMVn automatic capillary rolling ball microviscometer (Anton Paar, Scharnhausen, Germany) at $25 \pm 0.2{ }^{\circ} \mathrm{C}$ (four determinations per concentration). The $[\eta]\left(\mathrm{mL}^{\cdot} \mathrm{g}^{-1}\right)$ was estimated by extrapolation and averaging from the Huggins (Equation (1)), Kraemer (Equation (2)) and Solomon-Ciuta equations (Equation (3)):

$$
\frac{\eta_{s p}}{C}=[\eta]+[\eta]^{2} k_{H} C
$$

where $\frac{\eta_{s p}}{C}$ is the reduced viscosity $\left(\mathrm{mL} \cdot \mathrm{g}^{-1}\right), k_{H}$ is the Huggins' coefficient and $C$ is the polymer concentration $\left(\mathrm{g} \cdot \mathrm{mL}^{-1}\right)$.

$$
\ln \left([\eta]_{r e l}\right) / C=[\eta]+[\eta]^{2} k_{K} C
$$

where $\ln \left([\eta]_{\text {rel }}\right) / C$ is the inherent viscosity, $k_{K}$ is the Kraemer' constant and $C$ is the polymer concentration $\left(\mathrm{g} \cdot \mathrm{mL}^{-1}\right)$.

$$
[\eta]=\left[2\left(\eta_{s p}-\ln \eta_{\text {red }}\right)\right]^{1 / 2} / C
$$

where $\eta_{s p}$ is the specific viscosity, $\eta_{\text {red }}$ is the reduced viscosity and $C$ is the polymer concentration $\left(\mathrm{g} \cdot \mathrm{mL}^{-1}\right)$.

The viscosimetric mean average molar mass, $M$, was then estimated from the $[\eta]$ value using Mark-Houwink-Sakurada relationship (Equation (4)):

$$
[\eta]=K M^{\alpha}
$$

where, $K=7.4 \times 10^{-2}$ and $7.6 \times 10^{-2}\left(\mathrm{~mL} \cdot \mathrm{g}^{-1}\right)$ for $\mathrm{HMC}^{+} 28.8$ and $\mathrm{HMC}^{+} 15$, respectively, and $\alpha=0.76$ for both [60].

\subsubsection{Determination of the Degree of Esterification of Pectin}

In accordance with Rosenbohm et al. $5.0 \mathrm{mg}$ of pectin was dissolved in $0.8 \mathrm{~mL}$ of $\mathrm{D}_{2} \mathrm{O}$ under magnetic stirring at $55-60{ }^{\circ} \mathrm{C}$ for $1 \mathrm{~h}$, frozen at $-20{ }^{\circ} \mathrm{C}$ for $24 \mathrm{~h}$, lyophilised and then $1.0 \mathrm{~mL}$ of $\mathrm{D}_{2} \mathrm{O}$ added and the mixture stirred until fully dissolved [63]. The ${ }^{1} \mathrm{H}-\mathrm{NMR}$ spectra were acquired at $25{ }^{\circ} \mathrm{C}$ on a DRX 500 model spectrometer (Bruker). The DE (\%) is defined as the number of ester groups compared to the total number of carboxylic acid and ester groups. The DE was determined by comparing integrals of $\mathrm{H}-5$ adjacent to esters $\left(\mathrm{I}_{\mathrm{COOMe}}\right)$ to the sum of the integrals of $\mathrm{H}-5$ adjacent to esters ( $\left.\mathrm{I}_{\mathrm{COOMe}}\right)$ and $\mathrm{H}-5$ adjacent to carboxylates $\left(\mathrm{I}_{\mathrm{COO}-}\right)$. Due to the proximity (or overlap) of the signals for $\mathrm{H}-1$ and $\mathrm{H}-5 \mathrm{COOMe}$, it was only possible to determine the combined integrals for $\mathrm{H}-1$ and $\mathrm{H}-5_{\mathrm{COOMe}}\left(\mathrm{I}_{\mathrm{H} 1}+\mathrm{I}_{\mathrm{COOMe}}\right)$. This value can be introduced into the equation for the DE because the total number of the $\mathrm{H}-5$ protons is equal to the sum of the anomeric $\mathrm{H}-1$ protons: $\mathrm{I}_{\mathrm{COOMe}}+\mathrm{I}_{\mathrm{COO}-}=\mathrm{I}_{\mathrm{H} 1}$. The DE can be determined from DE $\left.(\%)=\left[\left(\mathrm{I}_{\mathrm{COOMe}}+\mathrm{I}_{\mathrm{H} 1}\right)-\mathrm{I}_{\mathrm{COO}-}\right) /\left[\left(\mathrm{I}_{\mathrm{COOMe}}+\mathrm{I}_{\mathrm{H} 1}\right)+\mathrm{I}_{\mathrm{COO}-}\right)\right] \times 100$.

\subsubsection{Determination of Intrinsic Viscosity $([\eta])$ and Molar Mass Estimation of Pectin}

The $[\eta]\left(\mathrm{mL}^{-} \mathrm{g}^{-1}\right)$ of pectin solutions prepared in $100 \mathrm{mM} \mathrm{NaCl}(0.125,0.250,0.500,1.000,1.500$ and $2.000 \mathrm{mg} \cdot \mathrm{mL}^{-1}$ ) was measured as described in Section 3.2.2. The mean average molar mass, $M$, was estimated from the $[\eta]$ values using the Mark-Houwink equation (Equation (4)). The constants used for pectin with a DE between 30.0-95.0\%, were $K=9.55 \times 10^{-2}\left(\mathrm{~mL} \cdot \mathrm{g}^{-1}\right)$ and $\alpha=0.73$ [64]. 


\subsubsection{Preparation of Nano- and Microparticles}

\section{Chitosan Solutions}

Chitosan solutions $\left(5.0 \mathrm{mg} \cdot \mathrm{mL}^{-1}, w / v\right)$ were prepared in $5 \%$ stoichiometric excess of $\mathrm{HCl}$ and in $100 \mathrm{mM} \mathrm{NaCl}$ by continuous magnetic stirring at room temperature $\left(25 \pm 1^{\circ} \mathrm{C}\right)$ for $14 \mathrm{~h}$, followed by filtration through $5.0 \mu \mathrm{m}$ membranes (EMD Millipore, Burlington, MA, USA). The $\zeta$-potential of the chitosan solutions $\left(5.0 \mathrm{mg} \cdot \mathrm{mL}^{-1}, w / v\right)$ was measured by mixed laser Doppler velocimetry and phase analysis light scattering (M3-PALS). A Malvern Zetasizer Nano ZS (Malvern Instruments Ltd., Worcestershire, UK) fitted with a red laser light $(\lambda=632.8 \mathrm{~nm})$ was used. The $\zeta$-potential was measured at pre-determined intervals over the $\mathrm{pH}$ range $1.0-8.0$, to assess the best conditions to obtain nanoand microparticles. Triplicate measurements were performed.

\section{Pectin Solutions}

Pectin solutions $\left(5.0 \mathrm{mg} \cdot \mathrm{mL}^{-1}, w / v\right)$ were prepared in $100 \mathrm{mM} \mathrm{NaCl}$ by continuous magnetic stirring at $50 \pm 1{ }^{\circ} \mathrm{C}$ for $1 \mathrm{~h}$ (to ensure the pectin would be solubilised) and then at room temperature $\left(25 \pm 1{ }^{\circ} \mathrm{C}\right)$ for $13 \mathrm{~h}$, followed by filtration through $5.0 \mu \mathrm{m}$ membranes (EMD Millipore). The $\zeta$-potentials of the pectin solutions $\left(5.0 \mathrm{mg} \cdot \mathrm{mL}^{-1}, w / v\right)$ was measured as described in the previous section.

\section{Pectin Purification}

This was done according to Bernabé et al. [65]. Briefly, pectin $\left(2.0 \mathrm{~g} \cdot \mathrm{L}^{-1}\right)$ was dissolved in $50 \mathrm{mM}$ $\mathrm{NaCl}$ by continuous magnetic stirring at $50 \pm 1{ }^{\circ} \mathrm{C}$ for $1 \mathrm{~h}$ and then, at room temperature $\left(25 \pm 1^{\circ} \mathrm{C}\right)$ for $13 \mathrm{~h}$. This solution was filtered successively through glass wool, sintered glass filters (pore diameters of 80.0, 60.0, 40.0 and $<10.0 \mu \mathrm{m}$ ) and membranes (5.0, 1.2, 0.8, 0.45 and $0.2 \mu \mathrm{m}$, EMD Millipore). The polysaccharide was precipitated by gradual addition of ethanol until a final $80.0 \%(v / v)$ alcohol concentration was obtained. The precipitate was removed by centrifugation (Sorvall, R-5 plus model, Langenselbold, Germany) at $7000 \mathrm{rpm}, 10^{\circ} \mathrm{C}$ for $30 \mathrm{~min}$. The solid was washed with ethanol/water mixtures $(70 / 30,80 / 20,90 / 10$ and 100/0) for 5 min each. The purified polymer was dried at room temperature $\left(25 \pm 1^{\circ} \mathrm{C}\right)$ for $48 \mathrm{~h}$.

\subsubsection{Preparation of Nano- and Microparticles}

Nano- and microparticles were prepared by electrostatic self-assembly according to the method reported by Fuenzalida et al. [66]. Briefly, chitosan-pectin mixed systems were prepared at $0.10,0.25$, $0.50,0.75,1.00,1.33,2.00,4.00$ and 5.00 charge equivalent ratios (equiv. $\left.\times \mathrm{L}^{-1}\right)\left(\mathrm{n}^{+} / \mathrm{n}^{-}\right)$, and $1.0 \times 10^{-6}$ and $2.0 \times 10^{-6} \mathrm{M}$ total charge $\left(\mathrm{n}^{+}+\mathrm{n}^{-}\right)$. The formation and optimal conditions to obtain nano- and micro-particles were screened by preparing the mixtures in a 96-well microplate (final volume $250 \mu \mathrm{L}$ ). An appropriate aliquot of chitosan solution $\left(5.0 \mathrm{mg} \cdot \mathrm{mL}^{-1}, w / v\right)$ was added into each microwell. An aliquot of mixed pectin $\left(5.0 \mathrm{mg} \cdot \mathrm{mL}^{-1}, w / v\right)$ and $\mathrm{NaCl}(100 \mathrm{mM})$ was added into the chitosan solution and mixed thoroughly by flushing the mixture in and out of the pipette tip. The conversion of the final solution (chitosan + pectin $+\mathrm{NaCl}$ ) from a clear/limpid to turbid/opalescent appearance, was taken as preliminary evidence of nanoparticle formation. When necessary, isolated nano- and micro-particles solutions were obtained by centrifugation $\left(10,000 \times g, 20^{\circ} \mathrm{C}\right.$ for $\left.40 \mathrm{~min}\right)$ using Eppendorf tubes containing $15 \mu \mathrm{L}$ of glycerol. The pellets were re-suspended in $100 \mu \mathrm{L}$ of $100 \mathrm{mM} \mathrm{NaCl}$.

Insulin-loaded nano- and microparticles were prepared by considering the best charge ratios $\left(n^{+} / n^{-} 0.25\right.$ and 5.00$)$ and total equiv. charge $\left(1.0 \times 10^{-6} M\right)$ results. A portion $(30.0 \%)$ of the charges of one polymer was substituted with insulin charges. Insulin $\left(5.0 \mathrm{mg} \cdot \mathrm{mL}^{-1}\right)$ was dissolved in one of the following solutions: $10 \mathrm{mM} \mathrm{NaOH} / 100 \mathrm{mM} \mathrm{NaCl}$ (charge ratio $\left.\left(\mathrm{n}^{+} / \mathrm{n}^{-}\right) 0.25\right)$ or $100 \mathrm{mM} \mathrm{NaCl}$, $\mathrm{pH}$ adjusted to 2.70 (charge ratio $\left(\mathrm{n}^{+} / \mathrm{n}^{-}\right) 5.00$ ). 


\subsubsection{Zeta-potential and Particle Size Determination of Nano- and Microparticles}

Nano- and microparticles suspensions were prepared at charge ratios $\left(\mathrm{n}^{+} / \mathrm{n}^{-}\right) 0.25$ and 5.00 , $1.0 \times 10^{-6}$ total charge and in $100 \mathrm{mM} \mathrm{NaCl}$ solution. The particle size distribution was obtained by dynamic light scattering with non-invasive back scattering (DLS-NIBS) at $173^{\circ}$ with automatic gain using a Malvern Zetasizer Nano ZS. The $\zeta$-potential was measured as mentioned previously. All measurements were recorded in triplicate at $25 \pm 2{ }^{\circ} \mathrm{C}$.

\subsubsection{Production Yield}

Nano- and microparticles, produced with and without insulin, were centrifuged $\left(20^{\circ} \mathrm{C}, 10,000 \times g\right.$, $40 \mathrm{~min}$ ). The supernatant was removed, and the pellets were frozen at $-20^{\circ} \mathrm{C}$ and lyophilised for $48 \mathrm{~h}$. The production yield of the particles was calculated from the masses of chitosan, pectin, insulin (or not) and $\mathrm{NaCl}$ used in the initial suspension preparation and the mass of the pellet formed (Equation (5)):

$$
\text { Yield }(\%)=\frac{M_{\text {pellet }}}{\left(M_{c}+M_{p}+M_{\text {ins }}+M_{\mathrm{NaCl}}\right)} \times 100
$$

where, $M_{\text {pellet }}$ is the mass of particles obtained after lyophilised process and $M_{c}, M_{p}, M_{\text {ins }}$ and $M_{\mathrm{NaCl}}$ are the respective initial masses of chitosan, pectin, insulin and sodium chloride used for nano- and microparticles formation.

\subsubsection{Stability Tests}

The colloidal stability of the systems was assessed as described elsewhere [67]. Briefly, the isolated nano- and microparticle solutions were incubated in $150 \mathrm{mM} \mathrm{NaCl}$ (adjusted $\mathrm{pH}$ to 7.4 using $0.1 \mathrm{M}$ $\mathrm{NaOH}$ and $0.1 \mathrm{M} \mathrm{HCl}$ ), MEM (pH 7.4), SGF (pH 1.2) and SIF ( $\mathrm{pH}$ 6.8) in a microtiter plate incubator (Titramax model, Heidolph, Schwabach, Germany) at $37 \pm 0.1{ }^{\circ} \mathrm{C}$. At pre-determined times $(0,20$, $4060,90,120$, and $180 \mathrm{~min}$, and $24 \mathrm{~h}$ ) the particle size distribution was measured by DLS-NIBS as described in Section 3.2.7.

SGF solution. $\mathrm{NaCl}(0.4 \mathrm{~g})$ was solubilised in $180 \mathrm{~mL}$ of deionised water and adjusted to $\mathrm{pH} 1.2$ using $0.1 \mathrm{M} \mathrm{NaOH}$ and $0.1 \mathrm{M} \mathrm{HCl}$. After, the final volume was made up to $200 \mathrm{~mL}$. The $\mathrm{pH}$ was 1.2 .

SIF solution. $\mathrm{H}_{2} \mathrm{KPO}_{4}(1.36 \mathrm{~g})$ was dissolved in $50 \mathrm{~mL}$ of deionised water. Separately, $15.4 \mathrm{~mL}$ of $0.2 \mathrm{M} \mathrm{NaOH}$ and $100 \mathrm{~mL}$ of deionised water were combined. The solutions were homogenised together and adjusted to $\mathrm{pH} 6.8$ using $0.1 \mathrm{M} \mathrm{NaOH}$ and $0.1 \mathrm{M} \mathrm{HCl}$. After, the final volume was made up to $200 \mathrm{~mL}$. The $\mathrm{pH}$ was 6.8. Both the SGF and SIF solutions were prepared according to the United States Pharmacopeia XIX.

\subsubsection{Insulin Encapsulation Efficiency}

The insulin EE in the different systems was determined using the protocol described by Marschütz and Bernkop-Schnürch [68], as modified by Krauland and Alonso [69]. The supernatant obtained after isolation was filtered $(0.22 \mu \mathrm{m}$, Millipore) and then a $5.0 \mu \mathrm{L}$ aliquot injected into a HPLC system (model X-LC, Jasco, Easton, PA, USA) equipped with a peptide C18 reverse phase column (Aeris wide pore XB-C18, $3.6 \mu \mathrm{m} 150 \times 2.1 \mathrm{~mm}$, Phenomenex, Aschaffenburg, Germany) at room temperature $\left(25^{\circ} \mathrm{C}\right)$. Gradient elution was performed as follows: $0.3 \mathrm{~mL} \cdot \mathrm{min}^{-1}$ flow rate for the first $5 \mathrm{~min}$; linear gradient from $70.0 \% \mathrm{~A} / 30.0 \% \mathrm{~B}$ to $39.0 \% \mathrm{~A} / 61.0 \% \mathrm{~B}$ (eluent A: $0.1 \%$ trifluoracetic acid in water; eluent $\mathrm{B}$ : acetonitrile). Insulin and/or degradation products were detected at $\lambda=220 \mathrm{~nm}$ with a UV-Vis detector. Insulin concentrations were quantified from integrated peak areas and calculated using a calibration curve. The EE of insulin was calculated from the following equation (Equation (6)):

$$
\text { Encapsulation efficiency }(E E, \%)=\frac{\text { Total }_{\text {Ins }}-\text { Free }_{\text {Ins }}}{\text { Total }_{\text {Ins }}} \times 100
$$


where, Total ${ }_{\text {Ins }}$ is the total quantity of insulin used to load at nano- and microparticles and Free Ins $_{\text {in }}$ is the quantity of insulin not associated to the nano- and microparticles.

\subsubsection{Transmission Electron Microscopy}

Nano- and microparticles unloaded and loaded-insulin formulated using chitosan DA $28.8 \%$ at two different charge ratios $\left(\mathrm{n}^{+} / \mathrm{n}^{-}\right)(0.25$ and 5.00) were visualized by TEM. To this end, $20 \mu \mathrm{L}$ of freshly prepared samples were mixed with $20 \mu \mathrm{L}$ of $1 \%(w / v)$ uranyl acetate for negative staining. Afterwards $8 \mu \mathrm{L}$ of samples were deposited onto a copper grid covered with Formvar ${ }^{\circledR}$ film. Excess liquid was blotted using filter paper. Images were captured using a JEM-1400 TEM (JEOL, Peabody, MA, USA) operating at $100 \mathrm{kV}$. Images were processed on an AMT 1k CCD (AMT, Woburn, MA, USA) using AMTV602 software (AMT, Woburn, MA, USA).

\subsubsection{Cytotoxicity (MTT Assay)}

\section{Cell Culture}

Caco-2-cells were cultured in $75 \mathrm{~cm}^{2}$ flasks using MEM supplemented with $10 \%$ foetal bovine serum, 1\% L-glutamine ( $200 \mathrm{mM})$ and $1 \%$ penicillin-streptomycin (10,000 units penicillin, 10,000 units streptomycin in $0.9 \% \mathrm{NaCl}$ ). The cultures were maintained in a humid atmosphere at $37^{\circ} \mathrm{C}$ with $5 \%$ $\mathrm{CO}_{2}$ (Sanyo MCO-19AIC, Panasonic Biomedical Sales Europe BV, AZ, Etten-Leur, The Netherlands). Cells from passages 43, 44, 46 and 50 were used for all experiments, which were carried out as independent triplicates on different days. After reaching microscopic confluence, the cells were washed with $10 \mathrm{~mL}$ PBS and trypsinised with $10 \mathrm{~mL}$ of $0.05 \%$ trypsin in EDTA $(1 \times)$ buffer. After detachment, $10 \mathrm{~mL}$ of MEM was added to the trypsin buffer. The cell suspension was centrifuged at $1000 \mathrm{rpm}$ for $5 \mathrm{~min}$ (Rotina $420 \mathrm{R}$, Andreas Hettich GmbH, Tuttlingen, Germany). The excess medium was removed, and the cell pellet was resuspended in $1 \mathrm{~mL}$ MEM. A $10 \mu \mathrm{L}$ aliquot of the cell suspension was diluted with $90 \mu \mathrm{L}$ trypan blue, and the number of cells was counted with an improved Neubauer chamber before seeding. The cells were sub-cultured by splitting at a 1:10 ratio.

\section{MTT Assay}

This assay was used to evaluate the cytotoxicity of the formulations and components. Briefly, $100 \mu \mathrm{L}$ of cell suspension was transferred to each well of a 96-well tissue culture plate $\left(\sim 10^{4}\right.$ cells per well or $\sim 10^{5}$ cells $\times \mathrm{mL}^{-1}$ ) and allowed to attach for $24 \mathrm{~h}$. The cells were washed twice with supplement-free MEM before the sample was added and the cells were then incubated for $3 \mathrm{~h}$. Nanoand micro-particles prepared in different charge ratio $\left(\mathrm{n}^{+} / \mathrm{n}^{-} 0.25\right.$ and 5.00) using chitosan with different DA (15.0\% and 28.8\%) were isolated as detailed previously and re-suspended in $100 \mu \mathrm{L}$ of MEM. Aliquots $(100 \mu \mathrm{L})$ were then placed into each well and incubated for $4 \mathrm{~h}$. The samples were removed and replaced with $100 \mu \mathrm{L}$ supplement-free MEM. A MTT solution in PBS with thiazolyl blue tetrazolium bromide $\left(25 \mu \mathrm{L}, 5.0 \mathrm{mg} \cdot \mathrm{mL}^{-1}\right)$ was added to each well. After $4 \mathrm{~h}$, the medium was again removed, and DMSO was added to dissolve the MTT formazan crystals. The plates were protected against light during agitation at $100 \mathrm{rpm}$ for $15 \mathrm{~min}$ in an orbital shaker (KS 4000i control model, IKA, Staufen, Germany). After, the absorbance was measured at $\lambda=570 \mathrm{~nm}$ with a microplate reader (Safire, Tecan AG, Salzburg, Austria). Positive (cell death using $100 \mu \mathrm{L}$ of Triton X 4.0\% $(w / v)$ ) and negative (cell death using $100 \mu \mathrm{L}$ of MEM without particles) controls were used to determine the relative cell viability. Each concentration was studied in eight microplates, and the biological experiments were carried out in triplicate [70].

\subsubsection{Insulin Release: In Vitro Tests}

Insulin release assays were performed according to Bagre et al. [43]. Chitosan of different DA $(15.0 \%$ and $28.8 \%)$ and pectin solutions were prepared to obtain isolated nano- and microparticles loaded with insulin at charge ratio $\left(\mathrm{n}^{+} / \mathrm{n}^{-}\right) 5.0$ and total charge of $1.0 \times 10^{-6}$. The nano- and 
microparticle dispersions $(100 \mu \mathrm{L})$ were placed into Eppendorf tubes containing $900 \mu \mathrm{L}$ of SIF or SGF and maintained in an incubator (Titramax model, Heidolph) at $37 \pm 1^{\circ} \mathrm{C}$. Aliquots were removed at pre-determined times $(0,15,30,45,60,90$ and $120 \mathrm{~min})$ and the insulin content was determined as described in Section 3.2.10. The insulin release experiments were carried out in triplicate.

\subsection{Statistical Analysis}

The data were appraised using the Statistica program version 7.0 (Statistica Inc., Palo Alto, CA, USA). Differences between the means were detected by Tukey's multiple comparisons test.

\section{Conclusions}

Pectin-chitosan nano- and microparticles were obtained by electrostatic self-assembly. The small particle sizes, ranging from 240-1900 nm were amenable to encapsulate insulin. The optimal charge ratio $\left(\mathrm{n}^{+} / \mathrm{n}^{-}\right)$for nano- and microparticles formation were 0.25 (excess of pectin charges) and 5.00 (excess of chitosan charges), which produced the highest product yield (maximum 33.8\%). Insulin was efficiently encapsulated (from 34.0-62.0\%) into the particles due to a strong interaction between the oppositely charged polysaccharides. Controlled insulin release occurred under SIF ( $\mathrm{pH}$ 6.8) conditions, and less than $13.0 \%$ was released in SGF ( $\mathrm{pH} 1.2,2 \mathrm{~h}$ ). The non-cytotoxicity (using chitosan with DA $15.0 \%$ ) of the proposed system seems to be advantageous due to its simple manufacture, offering an alternative route for oral insulin delivery with good stability under acidic (stomach) and basic (intestinal) conditions.

Acknowledgments: This work was supported by CAPES [grant number BEX 6348/13-0)] and FAPESP (grant number 2016/18142-4) (Brazil). The authors would like to thank the Department of Biology of University Münster (Germany) and the School of Food Science and Nutrition of University of Leeds (UK), for hosting the PhD and post-doctoral stays, respectively, for VBVM. We thank Martin Fuller (Astbury Centre for Structural and Molecular Biology, University of Leeds) for technical assistance in TEM imaging. We also thank SIAQ (Sociedad Iberoamericana de Quitina) for the partial cover of the publication fees.

Author Contributions: V.B.V.M. and F.M.G. conceived and designed the experiments; V.B.V.M. and S.M.S.S.P. performed the experiments; V.B.V.M., C.M.P.Y. and F.M.G. analyzed the data; V.B.V.M., C.M.P.Y., F.M.G. and T.T.F. wrote the paper.

Conflicts of Interest: The authors declare no conflict of interest.

\section{References}

1. Ghaffari, A.; Navaee, K.; Oskoui, M.; Bayati, K.; Rafiee-Tehrani, M. Preparation and characterization of free mixed-film of pectin/chitosan/Eudragit@RS intended for sigmoidal drug delivery. Eur. J. Pharm. Biopharm. 2007, 67, 175-186. [CrossRef] [PubMed]

2. Rashidova, S.S.; Milusheva, R.Y.; Semenova, L.N.; Mukhamedjanova, M.Y.; Voropaeva, N.L.; Vasilyeva, S.; Faizieva, R.; Ruban, I.N. Characteristics of interactions in the pectin-chitosan system. Chromatographia 2004, 59, 779-782. [CrossRef]

3. Maciel, V.B.V.; Yoshida, C.M.P.; Franco, T.T. Chitosan/pectin polyelectrolyte complex as a $\mathrm{pH}$ indicator. Carbohydr. Polym. 2015, 132, 537-545. [CrossRef] [PubMed]

4. Jardim, K.V.; Joanitti, G.A.; Azevedo, R.B.; Parize, A.L. Physico-chemical characterization and cytotoxicity evaluation of curcumin loaded in chitosan/chondroitin sulfate nanoparticles. Mater. Sci. Eng. C 2015, 56, 294-304. [CrossRef] [PubMed]

5. Chen, M.C.; Mi, F.L.; Liao, Z.X.; Hsiao, C.W.; Sonaje, K.; Chung, M.F.; Hsu, L.W.; Sung, H.W. Recent advances in chitosan-based nanoparticles for oral delivery of macromolecules. Adv. Drug Deliv. Rev. 2013, 65, 865-879. [CrossRef] [PubMed]

6. Sonia, T.A.; Sharma, C.P. An overview of natural polymers for oral insulin delivery. Drug Discov. Today 2012, 17, 784-792. [CrossRef] [PubMed]

7. Rao, J.P.; Geckeler, K.E. Polymer nanoparticles: Preparation techniques and size-control parameters. Prog. Polym. Sci. 2011, 36, 887-913. [CrossRef] 
8. Kreuter, J. Nanoparticles. In Colloidal Drug Delivery Systems, 1st ed.; Kreuter, J., Ed.; Marcel Dekker Inc.: New York, NY, USA, 1994; pp. 219-342.

9. Ninan, N.; Muthiah, M.; Park, I.K.; Elain, A.; Thomas, S.; Grohens, Y. Pectin/carboxymethyl cellulose/ microfibrillated cellulose composite scaffolds for tissue engineering. Carbohydr. Polym. 2013, 98, 877-885. [CrossRef] [PubMed]

10. Fonte, P.; Araújo, F.; Silva, C.; Pereira, C.; Reis, S.; Santos, H.A.; Sarmento, B. Polymer-based nanoparticles for oral insulin delivery: Revisited approaches. Biotechnol. Adv. 2015, 33, 1342-1354. [CrossRef] [PubMed]

11. Whiting, D.R.; Guariguata, L.; Weil, C.; Shaw, J. IDF diabetes atlas: Global estimates of the prevalence of diabetes for 2011 and 2030. Diabetes Res. Clin. Pract. 2011, 94, 311-321. [CrossRef] [PubMed]

12. Wild, S.; Roglic, G.; Green, A.; Sicree, R.; King, H. Global prevalence of diabetes: Estimates for the year 2000 and projections for 2030. Diabetes Care 2004, 27, 1047-1053. [CrossRef] [PubMed]

13. Herrero, E.P.; Alonso, M.J.; Csaba, N. Polymer-based oral peptide nanomedicines. Ther. Deliv. 2012, 3, 657-668. [CrossRef] [PubMed]

14. Alai, M.S.; Lin, W.J.; Pingale, S.S. Application of polymeric nanoparticles and micelles in insulin oral delivery. J. Food Drug Anal. 2015, 23, 351-358. [CrossRef] [PubMed]

15. Khafagy, E.-S.; Morishita, M.; Onuki, Y.; Takayama, K. Current challenges in non-invasive insulin delivery systems: A comparative review. Adv. Drug Deliv. Rev. 2007, 59, 1521-1546. [CrossRef] [PubMed]

16. Mukhopadhyay, P.; Sarkar, K.; Chakraborty, M.; Bhattacharya, S.; Mishra, R.; Kundu, P.P. Oral insulin delivery by self-assembled chitosan nanoparticles: In vitro and in vivo studies in diabetic animal model. Mater. Sci. Eng. C 2013, 33, 376-382. [CrossRef] [PubMed]

17. Hosseininasab, S.; Pashaei-Asl, R.; Khandaghi, A.A.; Nasrabadi, H.T.; Nejati-Koshki, K.; Akbarzadeh, A.; Joo, S.W.; Hanifehpour, Y.; Davaran, S. Synthesis, characterization, and in vitro studies of PLGA-PEG nanoparticles for oral insulin delivery. Chem. Biol. Drug Des. 2014, 84, 307-315. [CrossRef] [PubMed]

18. Morishita, M.; Peppas, N.A. Is the oral route possible for peptide and protein drug delivery? Drug Discov. Today 2006, 11, 905-910. [CrossRef] [PubMed]

19. Al-Azi, S.O.S.M.; Tan, Y.T.F.; Wong, T.W. Transforming large molecular weight pectin and chitosan into oral protein drug nanoparticulate carrier. React. Funct. Polym. 2014, 84, 45-52. [CrossRef]

20. Mukhopadhyay, P.; Chakraborty, S.; Bhattacharya, S.; Mishra, R.; Kundu, P.P. pH-sensitive chitosan/alginate core-shell nanoparticles for efficient and safe oral insulin delivery. Int. J. Biol. Macromol. 2015, 72, 640-648. [CrossRef] [PubMed]

21. Andreani, T.; Miziara, L.; Lorenzon, E.N.; Souza, A.L.R.; Kiill, C.P.; Fangueiro, J.F.; Garcia, M.L.; Gremiao, P.D.; Silva, A.M.; Souto, E.B. Effect of mucoadhesive polymers on the in vitro performance of insulin-loaded silica nanoparticles: Interactions with mucin and biomembrane models. Eur. J. Pharm. Biopharm. 2015, 93, 118-126. [CrossRef] [PubMed]

22. Chronopoulou, L.; Nocca, G.; Castagnola, M.; Paludetti, G.; Ortaggi, G.; Sciubba, F.; Bevilacqua, M.; Lupi, A.; Gambarini, G.; Palocci, C. Chitosan based nanoparticles functionalized with peptidomimetic derivatives for oral drug delivery. New Biotechnol. 2016, 33, 23-31. [CrossRef] [PubMed]

23. Zhang, L.; Wang, J.; Ni, C.; Zhang, Y.; Shi, G. Preparation of polyelectrolyte complex nanoparticles of chitosan and poly(2-acry1amido-2-methylpropanesulfonic acid) for doxorubicin release. Mater. Sci. Eng. C 2016, 58, 724-729. [CrossRef] [PubMed]

24. Kleine-Brüggeney, H.; Zorzi, G.K.; El-Gueddari, N.E.; Moerschbacher, B.M.; Goycoolea, F.M. A rational approach towards the design of chitosan-based nanoparticles obtained by ionotropic gelation. Colloid Surf. B 2015, 135, 99-108. [CrossRef] [PubMed]

25. Kumar, A.; Ahuja, M. Carboxymethyl gum kondagogu-chitosan polyelectrolyte complex nanoparticles: Preparation and characterization. Int. J. Biol. Macromol. 2013, 62, 80-84. [CrossRef] [PubMed]

26. Coimbra, P.; Ferreira, P.; Sousa, H.C.; Batista, P.; Rodrigues, M.A.; Correia, I.J.; Gil, M.H. Preparation and chemical and biological characterization of a pectin/chitosan polyelectrolyte complex scaffold for possible bone tissue engineering applications. Int. J. Biol. Macromol. 2011, 48, 112-118. [CrossRef] [PubMed]

27. Vaarum, K.M.; Smidsrod, O. Structure-property relationship in chitosans. In Polysaccharides: Structural Diversity and Functional Versatility, 2nd ed.; Dumitriu, S., Ed.; Marcel Dekker Inc.: New York, NY, USA, 2005; pp. 625-660.

28. Rinaudo, M.; Pavlov, G.; Desbrières, J. Solubilization of chitosan in strong acid medium. Int. J. Polym. Anal. Charact. 1999, 5, 267-276. [CrossRef] 
29. McConaughy, S.D.; Stroud, P.A.; Boudreaux, B.; Hester, R.D.; McCormick, C.L. Structural characterization and solution properties of a galacturonatepolysaccharide derived from Aloe vera capable of in situ gelation. Biomacromolecules 2008, 9, 472-480. [CrossRef] [PubMed]

30. Abodinar, A.; Smith, A.M.; Morris, G.A. A novel method to estimate the stiffness of carbohydrate polyelectrolyte polymers based on the ionic strength dependence of zeta potential. Carbohydr. Polym. 2014, 112, 6-9. [CrossRef] [PubMed]

31. Rolin, C. Commercial pectin preparations. In Pectins and their manipulation, 1st ed.; Seymour, C., Knox, P., Eds.; CRC Press: Boca Raton, FL, USA, 2002; pp. 222-241.

32. Giancone, T.; Torrieri, E.; Masi, P.; Michon, C. Protein-polysaccharide interactions: Phase behaviour of pectin-soy flour mixture. Food Hydrocoll. 2009, 23, 1263-1269. [CrossRef]

33. Goycoolea, F.M.; Brunel, F.; Gueddari, N.E.; Coggiola, A.; Lollo, G.; Moerschbacher, B.M.; Remuñán-López, C.; Delair, T.; Domard, A.; Alonso, M.J. Physical Properties and Stability of Soft Gelled Chitosan-Based Nanoparticles. Macromol. Biosci. 2016, 16, 1873-1882. [CrossRef] [PubMed]

34. Argüelles-Monal, W.; Cabrera, G.; Peniche, C.; Rinaudo, M. Conductimetric study of the interpolyelectrolyte reaction between chitosan and polygalacturonic acid. Polym. 2000, 41, 2373-2378. [CrossRef]

35. Fábregas, A.; Miñarro, M.; García-Montoya, E.; Pérez-Lozano, P.; Carrillo, C.; Sarrate, R.; Sánchez, N.; Ticó, J.R.; Suné-Negre, J.M. Impact of physical parameters on particle size and reaction yield when using the ionic gelation method to obtain cationic polymeric chitosan-tripolyphosphate nanoparticles. Int. J. Pharm. 2013, 446, 199-204. [CrossRef] [PubMed]

36. Zhang, H.; Zhao, Y. Preparation, characterization and evaluation of tea polyphenole-Zn complex loaded $\beta$-chitosan nanoparticles. Food Hydrocoll. 2015, 48, 260-273. [CrossRef]

37. Cerchiara, T.; Abruzzo, A.; Di Cagno, M.; Bigucci, F.; Bauer-Brandl, A.; Parolin, C.; Vitali, B.; Gallucci, M.C.; Luppi, B. Chitosan based micro- and nanoparticles for colon-targeted delivery of vancomycin prepared by alternative processing methods. Eur. J. Pharm. Biopharm. 2015, 92, 112-119. [CrossRef] [PubMed]

38. Woitiski, C.B.; Carvalho, R.A.; Ribeiro, A.J.; Neufeld, R.J.; Veiga, F. Strategies toward the improved oral delivery of insulin nanoparticles via gastrointestinal uptake and translocation. BioDrugs 2015, 22, $223-237$. [CrossRef]

39. Soliman, G.M.; Zhang, Y.L.; Merle, G.; Cerruti, M.; Barralet, J. Hydrocaffeic acid-chitosan nanoparticles with enhanced stability, mucoadhesion and permeation properties. Eur. J. Pharm. Biopharm. 2014, 88, 1026-1037. [CrossRef] [PubMed]

40. Lu, X.; Gao, H.; Li, C.; Yang, Y.W.; Wang, Y.; Fan, Y.; Wu, G.; Ma, J. Polyelectrolyte complex nanoparticles of amino poly(glycerol methacrylate)s and insulin. Int. J. Pharm. 2012, 423, 195-201. [CrossRef] [PubMed]

41. Goycoolea, F.M.; Valle-Gallego, A.; Stefani, R.; Menchicchi, B.; David, L.; Rochas, C.; Santander-Ortega, M.J.; Alonso, M.J. Chitosan-based nanocapsules: Physical characterization stability in biological media and capsaicin encapsulation. Colloid Polym. Sci. 2012, 290, 1423-1434. [CrossRef]

42. Russo, E.; Gaglianone, N.; Baldassari, S.; Parodi, B.; Cafaggi, S.; Zibana, C.; Donalisio, M.; Cagno, V.; Lembo, D.; Caviglioli, G. Preparation, characterization and in vitro antiviral activity evaluation of foscarnet-chitosan nanoparticles. Colloid Surf. B 2014, 118, 117-125. [CrossRef] [PubMed]

43. Bagre, A.O.; Jain, K.; Jain, N.K. Alginate coated chitosan core shell nanoparticles for oral delivery of enoxaparin: In vitro and in vivo assessment. Int. J. Pharm. 2013, 456, 31-40. [CrossRef] [PubMed]

44. Luo, Y.; Teng, Z.; Li, Y.; Wang, Q. Solid lipid nanoparticles for oral drug delivery: Chitosan coating improves stability, controlled delivery, mucoadhesion and cellular uptake. Carbohydr. Polym. 2015, 122, 221-229. [CrossRef] [PubMed]

45. Ubaidulla, U.; Khar, R.K.; Ahmad, F.J.; Sultana, Y.; Panda, A.K. Development and characterization of chitosan succinate microspheres for the improved oral bioavailability of insulin. J. Pharm. Sci. 2007, 96, 3010-3023. [CrossRef] [PubMed]

46. Bayat, A.; Dorkoosh, F.A.; Dehpour, A.R.; Moezi, L.; Larijani, B.; Junginger, H.E.; Rafiee-Tehrani, M. Nanoparticles of quaternized chitosan derivatives as a carrier for colon delivery of insulin: Ex vivo and in vivo studies. Int. J. Pharm. 2008, 356, 259-266. [CrossRef] [PubMed]

47. Calvo, P.; Remunan-Lopez, C.; Vila-Jato, J.L.; Alonso, M.J. Novel hydrophilic chitosan-polyethylene oxide nanoparticles as protein carriers. J. Appl. Polym. Sci. 1997, 63, 125-132. [CrossRef] 
48. Goycoolea, F.M.; Lollo, G.; Remuñán-López, C.; Quaglia, F.; Alonso, M.J. Chitosan-alginate blended nanoparticles as carriers for transmucosal delivery of macromolecules. Biomacromolecules 2009, 10, 1736-1743. [CrossRef] [PubMed]

49. Pan, Y.; Li, Y.; Zhao, H.; Zheng, J.M.; Xu, H.; Wei, G.; Hao, J.; Cui, F. Bioadhesive polysaccharide in protein delivery system: Chitosan nanoparticles improve the intestinal absorption of insulin in vivo. Int. J. Pharm. 2002, 249, 139-147. [CrossRef]

50. Loh, J.W.; Saunders, M.; Lim, L.Y. Cytotoxicity of monodispersed chitosan nanoparticles against the Caco-2 cells. Toxicol. Appl. Pharm. 2012, 262, 273-282. [CrossRef] [PubMed]

51. Duncan, R.; Izzo, L. Dendrimer biocompatibility and toxicity. Adv. Drug Deliv. Rev. 2015, 57, $2215-2237$. [CrossRef] [PubMed]

52. Vihola, H.; Laukkanen, A.; Valtola, L.; Tenhu, H.; Hirvonen, J. Cytotoxicity of thermosensitive polymers poly( $N$-isopropylacrylamide), poly( $N$-vinylcaprolactam $)$ and amphiphilically modified poly(N-vinylcaprolactam). Biomaterials 2005, 26, 3055-3064. [CrossRef] [PubMed]

53. Zhang, X.; Sun, M.; Zheng, A.; Cao, D.; Bi, Y.; Sun, J. Preparation and characterization of insulin-loaded bioadhesive PLGA nanoparticles for oral administration. Eur. J. Pharm. Sci. 2012, 45, 632-638. [CrossRef] [PubMed]

54. Rodriguez-Juan, C.; Perez-Blas, M.; Valeri, A.P.; Aguilera, N.; Arnaiz-Villena, A.; Pacheco-Castro, A.; Martin-Villa, J.M. Cell surface phenotype and cytokine secretion in Caco-2 cell cultures: Increased RANTES production and IL-2 transcription upon stimulation with IL-1 $\beta$. Tissue Cell 2001, 33, 570-579. [CrossRef] [PubMed]

55. Leonard, M.; Creed, E.; Brayden, D.; Baird, A.W. Evaluation of the Caco-2 monolayer as a model epithelium for iontophoretic transport. Pharm. Res. 2000, 17, 1181-1188. [CrossRef]

56. Loretz, B.; Bernkop-Schnurch, A. In vitro cytotoxicty testing of non-thiolated and thiolated chitosan nanoparticles for oral gene delivery. Nanotoxicology 2007, 1, 139-148. [CrossRef]

57. Biswas, A.; Chattopadhyay, M.; Sen, K.K.; Saha, M.K. Development and characterization of alginate coated low molecular weight chitosan nanoparticles as new carriers for oral vaccine delivery in mice. Carbohydr. Polym. 2015, 121, 403-410. [CrossRef] [PubMed]

58. Jia, X.; Chen, X.; Xu, Y.; Han, X.; Xu, Z. Tracing transport of chitosan nanoparticles and molecules in Caco-2 cells by fluorescent labelling. Carbohydr. Polym. 2009, 78, 323-329. [CrossRef]

59. Sadeghi, A.M.M.; Dorkoosh, F.A.; Avadi, M.R.; Weinhold, M.; Bayat, A.; Delie, F.; Gurny, R.; Larijani, B.; Rafiee-Tehrani, M.; Junginger, H.E. Permeation enhancer effect of chitosan and chitosan derivatives: Comparison of formulations as soluble polymers and nanoparticulate systems on insulin absorption in Caco-2 cells. Eur. J. Pharm. Biopharm. 2008, 70, 270-278. [CrossRef] [PubMed]

60. Avadi, M.R.; Sadeghi, A.M.M.; Mohammadpour, N.; Abedin, S.; Atyabi, F.; Dinarvand, R.; Rafiee-Tehrani, M. Preparation and characterization of insulin nanoparticles using chitosan and Arabic gum with ionic gelation method. Nanomedicine 2010, 6, 58-63. [CrossRef] [PubMed]

61. Lavertu, M.; Xia, Z.; Serreqi, A.N.; Berrada, M.; Rodrigues, A.; Wang, D.; Buschmann, M.D.; Gupta, A. A validated ${ }^{1} \mathrm{H}-\mathrm{NMR}$ method for the determination of the degree of deacetylation of chitosan. J. Pharm. Biomed. Anal. 2003, 32, 1149-1158. [CrossRef]

62. Rinaudo, M.; Milas, M.; Le Dung, P. Characterization of chitosan. Influence of ionic strength and degree of acetylation on chain expansion. Int. J. Biol. Macromol. 1993, 15, 281-285. [CrossRef]

63. Rosenbohm, C.; Lundt, I.; Christensen, T.M.I.E.; Young, N.W.G. Chemically methylated and reduced pectins: Preparation, characterisation by ${ }^{1} \mathrm{H}-\mathrm{NMR}$ spectroscopy, enzymatic degradation, and gelling properties. Carbohydr. Res. 2003, 338, 637-649. [CrossRef]

64. Anger, H.; Berth, G. Gel permeation chromatography and the Mark-Houwink relation for pectins with different degrees of esterification. Carbohydr. Polym. 1986, 6, 193-202. [CrossRef]

65. Bernabé, P.; Peniche, C.; Argüelles-Monal, W. Swelling behavior of chitosan/pectin polyelectrolyte complex membranes. Effect of thermal cross-linking. Polym. Bull. 2005, 55, 367-375. [CrossRef]

66. Fuenzalida, J.P.; Weikert, T.; Hoffmann, S.; Vila-Sanjurjo, C.; Moerschbacher, B.M.; Goycoolea, F.M.; Kolkenbrock, S. Affinity protein-based fret tools for cellular tracking of chitosan nanoparticles and determination of the polymer degree of acetylation. Biomacromolecules 2014, 15, 2532-2539. [CrossRef] [PubMed] 
67. Trapani, A.; Di Gioia, S.; Ditaranto, N.; Cioffic, N.; Goycoolea, F.M.; Carbone, A.; Garcia-Fuentes, M.; Conese, M.; Alonso, M.J. Systemic heparin delivery by the pulmonary route using chitosan and glycol chitosan nanoparticles. Int. J. Pharm. 2013, 447, 115-123. [CrossRef] [PubMed]

68. Marschütz, M.K.; Bernkop-Schnürch, A. Oral peptide drug delivery: Polymer-inhibitor conjugates protecting insulin from enzymatic degradation in vitro. Biomaterials 2000, 21, 1499-1507. [CrossRef]

69. Krauland, A.H.; Alonso, M.J. Chitosan/cyclodextrin nanoparticles as macromolecular drug delivery system. Int. J. Pharm. 2007, 340, 134-142. [CrossRef] [PubMed]

70. Gursoy, N.; Garrigue, J.S.; Razafindratsita, A.; Lambert, G.; Benita, S. Excipient effects on in vitro cytotoxicity of a novel paclitaxel selfemulsifying drug delivery system. J. Pharm. Sci. 2003, 92, 2411-2418. [CrossRef] [PubMed]

Sample Availability: Samples of the compounds are not available from the authors.

(C) 2017 by the authors. Licensee MDPI, Basel, Switzerland. This article is an open access article distributed under the terms and conditions of the Creative Commons Attribution (CC BY) license (http:/ / creativecommons.org/licenses/by/4.0/). 